\title{
Universiteit
}

Leiden

The Netherlands

\section{Relativization strategies in temporal adjunct clauses}

Lipták, A.K.; Rooryck, J.; Van, Craenenbroeck J.; Pica, P.

\section{Citation}

Lipták, A. K. (2005). Relativization strategies in temporal adjunct clauses. Linguistic Variation Yearbook, 5(1), 65-117. doi:10.1075/livy.5.04lip

Version:

Publisher's Version

License:

Licensed under Article 25fa Copyright Act/Law (Amendment Taverne)

Downloaded from: https://hdl.handle.net/1887/61775

Note: To cite this publication please use the final published version (if applicable). 


\title{
Relativization strategies in temporal adjunct clauses ${ }^{\star}$
}

\author{
Anikó Lipták \\ LUCL, Leiden University
}

This article takes a close look at the internal structure of temporal adverbial clauses in a number of unrelated languages, with a goal of uncovering the syntactic variation in these. The focus of discussion will be on temporal clauses that take the form of free relatives. It will be shown that there are minimally two different free relative strategies that can be found in temporal adverbial clauses: an ordinary free relative strategy with a gap in the position of a temporal modifier inside the relative clause and an IP-relativization strategy that involves relativization of the whole IP of the temporal clause. It will be shown that the latter strategy is a wh-relativization strategy as well and it shows similarity to clausal relativization (sentences of the type Tom arrived, after which Susan left).

The language in which the IP-relativization strategy will be isolated and fully analyzed is Hungarian. In this language before/after-clauses (among some other temporal clauses) clearly exhibit a relative clause structure that is different from ordinary relatives. The evidence found in Hungarian will prove useful for the analysis of some temporal clauses in other languages as well. It will be shown that IP-relativization most probably underlies after-clauses in German and Serbian, too. Further, a brief comparison of Hungarian temporal clauses to temporal clauses in other postpositional languages (Hindi and Basque) will suggest that the IP-relativization strategy in before/after-clauses can be thought of as a syntactic alternative to nominalization.

Keywords: head-raising analysis, nominalization, temporal adjunct, temporal modification, relative clause, relativization, Hungarian 


\section{Introduction and roadmap}

Adverbial clauses, and among them, temporal adverbial clauses often take the form of relative clauses across languages (Thompson \& Longacre 1985). In case they do, the temporal modifier of the subordinated event functions as the temporal modifier of the main clause event as well. Consider for example the when-clause in (1a), and its syntactic representation in (1b):

(1) a. Susan left when Tom arrived.

b. Susan left [CP when $_{\mathrm{i}}$ Tom arrived $\left.\mathrm{e}_{\mathrm{i}}\right]$.

In this sentence the temporal clause is an ordinary free relative clause, in which the relative pronoun when, roughly corresponding to an "at time $t$ " temporal modifier of the arrival event, undergoes movement. ${ }^{1}$ Due to the syntactic mechanism of relativization, the relative clause as a whole also denotes the time specification that characterizes the event internal to the relative clause (Tom's arrival). The temporal clause, denoting this time expression is then applied to the main clause event (Susan's leaving). This way, the embedded clause and the main clause events have the same specification in the temporal domain.

Interestingly, not all temporal clauses are constructed according to this mechanism. This can be due to various reasons. One is semantic in nature. In some temporal clauses, most notably in before/after-clauses, the temporal specifications of the main and embedded clauses are not the same. Thus in a before/after-clause, like in (2), the before-clause does not denote the same time expression that characterizes the event within itself (Tom's arrival):

(2) Susan left before Tom arrived.

Instead, before establishes an ordering relation between two events. This explains why a structure as in (1) is not available for a sentence like (2). To see this, let us see what the hypothetical structure for (2) would be, modelled upon when-type clauses in (1a). Adopting (1a) for a before-clause means letting the before-expression originate from the embedded clause, similarly to the whenexpression in (1a). The result is shown in (3). Since English exhibits no overt when operator in before-clauses, I use an empty operator instead of this item:

(3) Susan left $\left[\mathrm{CP}[\mathrm{pP} \text { before Op }]_{i}\right.$ Tom arrived $\left.\mathrm{e}_{\mathrm{i}}\right]$. wrong representation of a before-clause

As we have remarked above, however, the meaning of the before-clause is different from what a structure like (3) would mean. Before does not originate from 
inside the embedded clause. It is applied to the expression that characterizes the embedded event, which roughly corresponds to an "at time t" phrase. Thus, we come to the conclusion that there is no before-phrase modifying the event in the embedded clause. After has the exact same property. After and before originate from outside the temporal clause, not inside it. What can be a possible structure for a before/after-clause then? For example, one in which the preposition before takes a clause that denotes a when-expression (due to a when-phrase or an empty operator in it). This structure is completely parallel to (3), except that before in this case selects the time expression denoted by the whole clause as its argument:

(4) Susan left [pp before [CP $w_{h e n_{\mathrm{i}}} / \mathrm{Op}_{\mathrm{i}}$ Tom arrived $\left.\mathrm{e}_{\mathrm{i}}\right]$ ].

A structure in (4) gives us the proper meaning of a before-clause.

Next to before-clauses like (2), languages can make use of yet other possibilities for the expression of before-relations with clauses. The example in (5a) and its structure in (5b) show a case in which the temporal clause that before selects is a relative headed by a DP:

(5) a. Susan left before the time when Tom arrived.

b. Susan left [PP before [DP the time [CP when $_{\mathrm{i}}$ Tom arrived $\left.\left.\mathrm{e}_{\mathrm{i}}\right]\right]$ ].

Yet another possibility that languages can make use of is to nominalize the embedded event and feed that to before:

(6) a. Susan left before Tom's arriving.

b. Susan left [Pp before [DP [IP Tom arrive]-ing]].

As the reader can verify, the hypothetical structures in (4)-(6) deliver the desired semantics, namely one in which before gives the temporal ordering between the embedded and the main clause events.

The purpose of this paper is to show that there exists yet another, hitherto undiscovered strategy for the expression of before (or after) relations. In this strategy relativization takes place, but unlike in (4) or (5), it is not a when-phrase that is relativized, but $a$ whole IP. This relativization strategy can be found in Hungarian before- and after-clauses, among other languages. For illustration, consider the before-clause in (7): ${ }^{2}$

(7) Zsuzsa elment, mielőtt Tamás megjött. Zsuzsa left what-Before Tamás arrived 'Zsuzsa left before Tom arrived.' 
As I will argue in Sections 2 and 3, the temporal clause in (7) has the structure in $(8 \mathrm{a}, \mathrm{b})$ :

(8) a. Zsuzsa elment [pP $m i_{j}$-elótt [DP $\underline{\mathrm{mi}_{i}}\left[\mathrm{CP}\left[\mathrm{RelP}^{\mathrm{mi}} \mathrm{i}_{\mathrm{i}}[\mathrm{IP}\right.\right.$ Tamás megjött $\left.\left.\left.]\right]\right]\right]$. b.

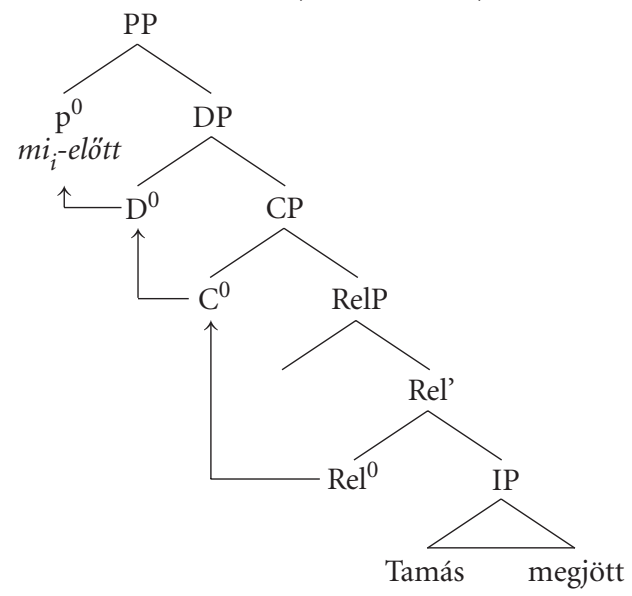

The present paper is dedicated to the description and analysis of the strategy illustrated in (8), which I will refer to as IP-relativization. IP-relativization involves relativization of functional material, that of a whole IP. As ( $8 \mathrm{a}, \mathrm{b}$ ) shows, this IP is base-generated as complement to a relative determiner ( $m i$ ' what') in an analysis that is reminiscent of the raising analysis of relative clauses (Kayne 1994). The relative DP that results is then taken as complement to before. Complementation to before gives rise to a further movement step, in which the relative pronoun moves up to before. The result is a wh-before-CP order that characterizes these types of clauses.

This newly discovered IP-relativization strategy in Hungarian has a cocktail of properties that make it different from well-known instances of free relativization of lexical categories. While IP-relativization does not share all of its properties with ordinary free relatives, it shares some of its properties with so-called clausal (non-restrictive) relatives, ${ }^{3}$ illustrated in (9):

(9) a. Egbert beteg, ami sajnálatos dolog.

Egbert sick REL-what unfortunate thing

'Egbert is sick, which is unfortunate.'

b. Tamás megjött, ami után Zsuzsa elment.

Tamás arrived REL-what AFTER Zsuzsa left

'Tamás arrived, after which Zsuzsa left.' 
The paper consists of two main parts. The first part gives a description and an analysis of Hungarian temporal clauses. The second part extends the results of the first part to other languages.

The first part starts out by laying out the scene of Hungarian temporal clauses in Section 2.1. and Section 2.2, with an exhaustive coverage of all standard temporal clauses. It will be shown that there are two types of temporal clauses in Hungarian, roughly along the split between since/when/until-clauses versus before/after-clauses. The two groups differ both in their morphology and their syntax. Section 2.3 will show that the since-type involves ordinary free relativization, which takes the form of correlativization when these clauses are in the left periphery. Section 2.4 and 3.1 will then turn to the characteristics of before-type temporals. It will be shown that their structure involves relative clause formation that operates on an IP, and further involves head movement of the relative determiner to an external postposition. Section 3.2 will explain the properties of before-type clauses. Sections 3.3 will draw parallels between temporal IP-relatives and clausal relatives.

In the second part the paper turns to German and Serbian to show that the uncovered IP-relativization strategy also exists in these languages as well (Section 4). The type of temporals to be discussed here are after-clauses. Section 5 briefly returns to the structural differences between before/after-vs. since/untilclauses once more and points out that postpositional languages accommodate them differently in their syntax. In Hindi, before/after-clauses are not relatives but nominalized clauses, and in Basque they are non-finite clauses. It will be shown that IP-relativization achieves the same goal as these strategies in providing a categorially suitable complement to a temporal postposition. Section 6 summarizes the results.

\section{Temporal clauses in Hungarian}

\subsection{Finite complementation and the wh-strategy}

Hungarian is an agglutinative language, which uses case-markers (bound morphemes) and postpositions (free morphemes) to express temporal relations. The temporal case-markers are: -kor 'at', -ig 'till/while', -rE 'by'; the temporal postpositions are: elött 'before', után 'after', óta 'since', alatt 'in', közben 'during.4 
In the clausal domain, temporals have two basic subordinating strategies: a finite complementation strategy and a wh-strategy. The finite strategy is available to postpositions only. It involves a distal demonstrative $a z$ 'that' with a postposition, followed by a complement clause introduced by the finite complementizer hogy: ${ }^{5}$

\section{(10) Azután [hogy Tamás megjött] Zsuzsa elment. that-AFTER that Tamás arrived Zsuzsa left 'After Tamás arrived, Zsuzsa left.'}

This temporal finite complementation strategy is similar to argumental finite complementation in general. The latter also contains a suitably case-marked pronominal followed by a finite clause:
(11) Pali nem hallott arról
[hogy Tamás megjött].
Pali not heard that-ABout that Tamás arrived
'Pali did not hear about the fact that Tamás arrived.'

The finite complementation strategy in temporals will not be dealt with in the rest of the paper.

The other available strategy in the formation of temporal clauses is a whstrategy. This involves wh-pronouns in clause initial positions, adorned by temporal case-markers and postpositions. This strategy is available to all temporal markers, case-markers and postpositions alike. The following examples illustrate the most frequently occurring temporal clauses at a glance: ${ }^{6}$

(12) [(A)mikor Péter nincs otthon], Anna egyedül van. REL-what-AT Péter is.not home Anna alone is 'When Péter is not at home, Anna is alone.'

[(A)mióta ismeri Annát], Péter boldog.
REL-what-SINCE knows Anna-ACC Péter happy
'Since he knows Anna, Péter is happy.'

(14) [(A)mikorra Anna bevásárolt], Péter megnézte a postáját. REL-what-AT-BY Anna PV-shopped Péter checked the mail-his-ACC 'By the time Anna finished shopping, Péter had checked his mail.'
[Ameddig
Anna vásárolt], Péter megnézte a ReL-what-TILL/while Anna shopped Péter checked the postáját. mail-his-ACC
'While Anna was shopping, Péter was checking his mail.' 
(16) [Mielőtt Péter elment otthonról], megnézte a postáját. what-BEFORE Péter left home checked the mail-his-ACC 'Before Péter left home, he checked his mail.'

(17) [Miután bevásárolt], Péter megnézte a postáját. what-AFTER PV-shopped Péter checked the mail-his-ACC 'After he did the shopping, Péter watched TV.'

(18) [Mialatt Anna bevásárolt], Péter megnézte a postáját. what-IN Anna PV-shopped Péter checked the mail-his-ACC 'While Anna did the shopping, Péter checked his mail.'

(19) [Miközben Anna vásárolt], Péter megnézte a postáját. what-During Anna shopped Péter checked the mail-his-ACC 'While Anna was shopping, Péter checked his mail.'

In all the above examples the temporal clauses are found in sentence-initial position, which, together with the sentence-final position, is the most natural place for temporal clauses in Hungarian.

As can be seen in these examples, all wh-clauses involve a wh-expression in clause-initial position, followed by a finite IP. The only observable difference between these examples is the morphological composition of the wh-phrase in them. The examples differ in whether they appear with an $a$-marker on the relative pronoun or not. This $a$-marker is a morpheme that adorns relative wh-phrases in Hungarian. In present-day Hungarian it is obligatory on relative pronouns in relative clauses with one pronominal (both headed and headless relatives), except for the wh-pronoun mely 'which', which frequently occurs without this marker as well (especially in writing): ${ }^{7}$

(20) a. Az a fiú, ${ }^{\star}(\mathrm{a}) \mathrm{ki}$ korán jött, ingyen bement. that the boy REL-who early came freely entered 'The boy who came early entered for free.'

b. Rossz az a határozat, (a)mely szerint mindenkinek bad the the law which ACCORDING everyone-DAT adózni kell. taxpay-INF need 'The law according to which everyone has to pay tax, is bad.'

Similarly to mely-relatives, the $a$-morpheme is also optional in multiple relatives. Multiple relatives are relative clauses in which we find more than one relative expression (Lipták 2000). For illustration, see (21): 
(21)

(A)ki (a)mit kért, az azt elvette.

REL-who REL-what-ACC wanted that that-ACC took

'Everyone took what he/she wanted.'

Coming back to temporal clauses, examples (12)-(14) showed that some whitems pattern with mely-relatives and multiple relatives when it comes to the optionality of a-marking: (a)mikor 'REL-what-AT', (a)mióta 'REL-what-SINCE' and (a)mire 'REL-what-BY' optionally occur with the $a$ - 'REL' morpheme. Clauses with mielott 'what-BEFORE', miután 'what-AFTER', mialatt 'what-IN', miközben 'what-DURING' (cf. (16)-(19)) on the other hand have to occur without such an $a$ - morpheme. ${ }^{8}$ The relative pronoun ameddig 'REL-what-WHILE' is exceptional in that this wh-item not only optionally but also obligatorily requires $a$ - (cf. 15). On the basis of the distribution of the relative marker then, temporal clauses belong to two distinct groups: an $a$-marked group, which utilizes $w h$-expressions which can appear with an $a$-marker and an $a$-less group that uses $w h$-expressions that cannot appear with it.

Interestingly, these two groups of temporal clauses, characterized by the optional presence or obligatory absence of $a$-marking also differ in syntactic properties as well, as the following section will show. A-marked temporal clauses have a syntax different from that of the $a$-less ones. According to the testimony of these facts, classifying temporal clauses and temporal wh-items into $a$-marked and $a$-less sorts reflects more than just an accidental morphological property: it corresponds to a structural distinction as well. The rest of Section 2 and Sections 3.1 and 3.2 are dedicated to show in what ways the syntax of these clauses differ, after which Section 3.3 will return to the intricacies of $a$-marking itself.

Before we proceed with this, however, a note on terminology is in order. Instead of using the morphological label " $a$-marked" versus " $a$-less" clauses, I will refer to the two groups as "since-type" clauses and "before-type" clauses respectively. The reason is that the presence of an actual $a$-morpheme in a particular example of a clause that falls in the $a$-marked category does not determine syntactic behaviour in any way. This group shows uniform syntactic behaviour, with or without an overt $a$ - morpheme. And this behaviour moreover matches that of clauses with ameddig 'REL-what-WHILE', in which $a$ - is obligatory. For these reasons, it is better to adopt a different name as shorthand for the two groups of temporal wh-expressions/clauses, one that does not suggest anything about the actual morphological appearance of the $w h$-words. I will refer to the two types as since-type versus before-type from now on. 
Table 1. The morphology of $w h$-expressions in temporal clauses in Hungarian

\begin{tabular}{lllll}
\hline morphology & wh-phrase & & English meaning & short name \\
\hline a-marked & (a)mikor & REL-what-AT & 'at' / 'when' & since-group \\
& (a)mikorra & REL-what-AT-BY & 'by (the time)' & \\
& (a)mióta & REL-what-SINCE & 'since' & \\
& ameddig & REL-what-TILL/wHILE & 'until' / 'while' & \\
a-less & mieloott & what-BEFORE & 'before' & before-group \\
& miután & what-AFTER & 'after' & \\
& mialatt & what-IN & 'while' & \\
& miközben & what-DURING & 'during' & \\
\hline
\end{tabular}

To summarize the discussion so far, Table 1 gives an overview of the two types of Hungarian temporal clauses/wh-items.

As mentioned before, the observed morphological split between the whitems is paired with syntactic differences between the two groups of temporal clauses as well: clauses formed with since-type $w h$-expressions pattern differently in their syntax from before-type ones. The next section spells out the syntactic differences in detail.

\subsection{Syntactic properties of since-type and before-type temporals}

The previous section showed that Hungarian temporal clauses involve a whstrategy that, depending on the wh-item, lacks or optionally involves $a$ marking by the relative morpheme, differentiating this way between beforetype clauses and since-type clauses. As far as membership in the two groups is concerned, at first blush it is difficult to find an obvious explanation for the observed split in morphology, as this split between the since-group and the before-group does not readily pair up with other obvious properties of these two groups of wh-expressions.

First of all, the two groups are not devided according to what kind of casemarker we find on the wh-element: a bound morpheme or a free morpheme, as the since-group contains both bound morphemes (-kor, -korra, -ig), and a postposition (óta). Neither is the grouping due to the kind or the complexity of the $w h$-item used: all examples feature the same $w h$-element, $m i$ 'what'. Semantics cannot be lying behind the split either, since items very similar in meaning, cf. (a) meddig 'REL-what-TILL/WHILE' and mialatt 'what-IN', both meaning 'while', belong to different groups. 
The morphological difference between since-type and before-type clauses, however, determines syntactic properties. We find differences between the two types in the following areas of syntactic behaviour:

(i) combination with noun phrases

(ii) availability of multiple wh-pronouns

(iii) availability of low/high readings

This section illustrates these differences one by one.

(i) Combination with noun phrases. Since-type and before-type temporal clauses differ in their distribution with nominals. Since-type temporals can freely occur after nominals with a temporal meaning, like a nap 'the day'. Before-type temporals on the other hand cannot modify such nominals. The contrast between the two clause-types is illustrated in (22) and (23). (22) shows a when-clause (an item from the since-group), and the examples in (23) show after-clauses, which belong to the before-group. As the latter examples show, after-clauses are ungrammatical in this position, regardless of whether the modified nominal is a DP or is inside an after-PP: ${ }^{9}$

(22) A nap [amikor Anna megjött] emlékezetes Péternek. the day REL-what-AT Anna arrived memorable Péter-DAT 'The day when Anna arrived is memorable for Péter.'
a. ${ }^{*}$ A nap [miután Anna megjött] emlékezetes Péternek. the day what-AfTer Anna arrived memorable Péter-DAT 'The day when Anna arrived is memorable for Péter.'
b. ${ }^{\star A}$ nap után [miután Anna megjött] Péter boldog volt. the day AFTER what-AFter Anna arrived Péter happy was 'After the day when Anna arrived Péter was happy.'

(ii) The availability of multiple wh-pronouns. A clear and very sharp difference between since-type and before-type temporals is that only the former can host multiple $w h$-pronouns. It has to be noted that relative clauses with multiple $w$ h-expressions are only available when the relative clause occurs in the sentence initial position (compare (21) above). Thus our examples have to feature temporal clauses in sentence initial position, too. (24) shows a temporal clause that contains the argumental relative pronoun aki 'REL-who' and the temporal relative amióta 'REL-what-SINCE':

(24) [Aki amióta ismeri Annát] az azóta szereti. REL-who REL-what-SINCE knows Anna-ACC that that-SINCE loves 'Everyone loves Anna since the time he/she knows her.' 
The same structure is ungrammatical when constructed with a before-type clause. The example provided features an alatt 'in' wh-phrase, a beforetype item:

(25) * ${ }^{*} \mathrm{Ki}$ mialatt énekel], az akkor boldog. who what-IN sings that that-AT happy 'Everyone is happy when he/she is singing.'

(iii) The availability of low/high readings. Temporal clauses in English (with the exception of while-clauses) allow both for short distance and long distance construals (Geis 1970; Larson 1988). These are called "high" and "low" readings respectively. Consider the English when-clause in (26) for illustration of these readings:

(26) I saw Mary in New York when she claimed she will be there.

This sentence is ambiguous. It can either mean that I saw Mary in New York at the time of her utterance, or at the time about which she claimed she will be in New York.

Coming back to Hungarian temporal clauses, this kind of ambiguity is only attested in since-type clauses, but not in before-type ones, as the following pair of examples illustrates. (27) involves a since-type clause, and (28) involves an after-type clause. The two types contrast in the availability of the low interpretation:

(27) Addig maradok, [ameddig mondod [hogy maradjak]]. that-wHILe stay-1sg REL-what-whiLe say-2sg that stay-subJ-1sG high: 'I stay until the time you keep saying that I should say.' low: 'I stay until time t. You say I should stay until time t.'

(28) Azután indulok el [miután szólsz [hogy Péter elindult]]. that-AFter leave-1sg PV what-AfTer tell-1sg that Péter left-3sg high: 'I leave after time $t$ when you tell me that Péter has left.' *low: 'I leave after time t. You tell me that Péter left at time t.'

While ameddig 'REL-what-WHILE' can be construed with both the lower or the higher predicate, miután 'what-AFTER' can only be construed with the higher one, that of (your) telling and not that of (Péter's) leaving. For comparison, note that ordinary relativization in Hungarian allows for both construals. In the following example, the relative pronoun akinek 'REL-who-DAT' can be understood either as the person to whom Péter said something or the person 
whose book has appeared. Relativization can thus give rise to both long or short construals:

(29) Meghívtam azt [akinek mondta Péter [hogy megjelent PV-invited that-ACC REL-who-DAT said Péter that appeared a könyve]]. the book-his high: 'I invited the person to whom Péter said that his book appeared.' low: 'I invited the person whose book Péter said has appeared.'

This completes the list of differences between since- and before-type temporal clauses that can be observed in the syntactic domain. The results of the present and the previous sections show that since-and before-type temporal clauses and temporal $w h$-phrases differ both in morphological and syntactic properties. The differences are listed in Table 2 at a glance.

Table 2. The properties of since- and before-type ( $w h$-expressions in) temporal clauses

\begin{tabular}{lcc}
\hline Properties & since-type & before-type \\
\hline relative morphology (i.e. $a$-marking) on the $w$ h-phrase & $\checkmark$ & $\star$ \\
combination with nominals & $\checkmark$ & $\star$ \\
multiple $w h$-pronouns & $\checkmark$ & $\star$ \\
high/low construals & high/low & high \\
\hline
\end{tabular}

As can be seen from this table, since- and before-type temporals clearly differ from each other in some non-trivial ways. This shows that the morphological difference between $w h$-phrases with and without the relative $a$-marker is indicative of some deeper structural difference: the two constructions have a different syntax. The remainder of the present section as well as Section 3 will give a detailed exposition of the syntactic differences.

\subsection{The structure of since-type temporals: Ordinary relatives}

We begin to uncover the structural properties of Hungarian temporal clauses by examining since-type temporals.

Next to showing relative morphology, since-type temporals show the syntactic properties that are characteristic of relative clause formation. What are these? First of all, they can modify nominals, as could be seen from property (i) in the previous section. Second, they can occur with multiple relative pronouns when in the left periphery (property (ii)), similarly to relative clauses 
(cf. (21)). As property (iii) showed, they allow for both high/low construals, just like ordinary relatives. All these pieces of evidence point to the unavoidable conclusion that these temporal clauses are run-of-the-mill relative clauses, in which a temporal phrase is relativized.

The morphological and syntactic evidence is fully consonant with the semantics of these clauses. To illustrate, let us take a since-clause, like (13) from above, repeated here as (30). Its internal structure is derived via relativizing a since-expression, as seen in $(31 \mathrm{a}, \mathrm{b})$. The resulting relative is then applied to the main clause, which gives us the sentence in (31c).

$$
\begin{aligned}
& \text { [(A)mióta ismeri Annát], Péter boldog. } \\
& \text { REL-what-SINCE knows Anna-ACC Péter happy } \\
& \text { 'Since he knows Anna, Péter is happy.' }
\end{aligned}
$$
a. [iP he knows Anna $\underline{t}$-SINCE]

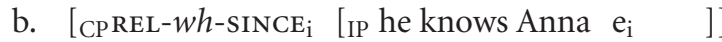
c. 'the time since which he knows Anna (Péter is happy)'

An independent piece of evidence for such relative-internal movement of the temporal expression in since-type clauses comes from until/while-temporals, which belong to the since-group in Hungarian. The aspectual restrictions on until/while-phrases give evidence for the movement step assumed in (31b). To see why, consider first the observation that until-phrases cannot combine with achievement predicates, but they can with activities, accomplishments or states (Karttunen 1974). This split between the two aspectual classes is shown in (32a) and $(32 b)$ :
a. ${ }^{\star} \mathrm{A}$ vonat öt óráig jött meg.
achievement the train five hour-TILL/WHILE arrived PV '`The train arrived until five o'clock.' Sára five hour-TILL/while chatted 'Sára was chatting until five o'clock.'
b. Sára öt óráig beszélgetett. activity predicate

In a parallel manner to (32a), until-clauses in Hungarian cannot contain an achievement predicate, as (33) illustrates: ${ }^{10}$

(33) *Sára beszélgetett [ameddig a vonat megjött]. Sára chatted REL-what-TILL/WHILE the train arrived 'Sára was chatting until the train arrived.' 
Given that only achievement predicates give rise to ungrammaticality with until-expressions, it must be the embedded predicate that causes the incompability in (33), giving rise to the ungrammaticality of the whole sentence. This in turn shows that the until-phrase ameddig 'REL-what-TILL/WHILE' modifies the embedded event, i.e. it originates from inside the temporal clause. If it originated outside the temporal clause, aspectual restrictions would not be observed in exactly the same manner as they are in (32a).

The proposed analysis in (31) explains all the properties of these clauses that were observed in the previous section. First of all, it can easily explain morphology. If these temporal clauses are relative clauses, the wh-expression in them is a relative pronoun. As they are relative pronouns, it is expected that they can be marked with the usual relative pronoun marker $a$ - morpheme. This is indeed the case for all members of the since-group.

Coming back now to the properties (i)-(iii) listed in the previous section, these can also be explained without further assumptions. The fact that a sincetype temporal clause can modify a nominal (property (i)) is beyond doubt due to these clauses being relative clauses. The same fact also explains why they can contain multiple relative pronouns (property (ii)): all Hungarian free relative clauses can have multiple relative pronouns, in the so-called correlativization strategy (Lipták 2005). Correlativization is a special relative clause formation strategy in which the relative clause appears to the left of the item it modifies. The two are syntactically independent from each other and do not form a constituent at any point in the derivation. Most crucially, the modified item is not the head of the relative clause. This gives rise to the possibility of having multiple relative pronouns in these clauses: if these relatives were headed relatives, they could only contain one pronominal, since there can only be one head to every relative clause. Not being headed structures, correlatives can contain multiple pronominals.

The fact that since-temporals share the structure of ordinary free relatives means that they, too, can take part in the correlativization strategy and thus involve multiple instances of relative pronouns. The movement steps underlying such a temporal clause for (24), repeated here as (34a) are shown in (34b):

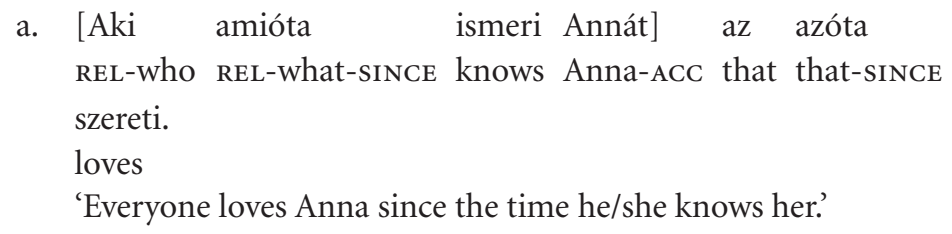


b. [CPREL-who j REL-what-SINCE $_{i}$ [IP e e knows Anna-ACC e e $\left.e_{i}\right]$

Property (iii), the availability of both high and low construals, is due to the fact that Hungarian allows for long relativization across a finite $\mathrm{CP}$, as was shown above (cf. 29). For the temporal clause in (35a) (example (27) above), this means that the temporal phrase can be extracted either out of the main clause as shown in (35b), or out of the embedded clause (35c). The former gives rise to the high construal and the latter to the low one:
a. Addig maradok, [ameddig mondod [hogy that-TILL/WHiLE stay-1sG REL-what-TILL/wHILE say-1sG that maradjak]]. stay-IMP-1SG
b. I stay [CP REL-wh-TILL/WHILE $\mathrm{W}_{i}$ you say $\mathrm{e}_{\mathrm{i}}$ [CP I should stay ]] high: 'I stay until the time you keep saying that I should say.'
c. I stay [CP REL-wh-TILL/WHILE $\mathrm{W}_{\mathrm{i}}$ you say [CP I should stay $\mathrm{e}_{\mathrm{i}}$ ]] low: 'I stay until time t. You say I should stay until time t.'

As we see, the observed properties of temporal clauses of the since-type follow from an analysis that assigns relative clause status to them. In this analysis the temporal modifier of the embedded event undergoes relativization. The result is a free relative clause that denotes the same temporal expression as the embedded temporal modifier. The meaning of these clauses can thus be transparently read off this relative clause structure. Syntactically, the relative clause analysis explains why we find wh-prominals in these clauses that behave exactly like ordinary relative pronouns when it comes to placement possibilities (low and high readings) and possible multiple occurences as well. The relative clause nature of these temporal clauses also explains why they can modify nominal expressions.

Summing up, this section provided evidence for the unavoidable conclusion that since-type temporals have the structure of ordinary relativization. As a result, these clauses exhibit properties that are completely parallel to the properties of ordinary relative clauses in all respects.

\subsection{Why are before-type temporals different?}

With the structure of since-type temporals in place, we can return to the analysis of before-type clauses. We have seen in Section 2.2 that these clauses exhibit 
different properties from since-type temporals. The obvious question is, why are before-type temporals different from since-type clauses?

For two items in the before-group semantics gives us a clue. It is easy to see why the syntax of before/after-clauses must be different from since-type clauses. Unlike since-type clauses, the meaning of a before/after-clause cannot be derived by relativizing a before/after-expression. Relativizing a beforelafterPP would result in a meaning that is crucially not the meaning of before/after clauses, as Section 1 has pointed out in detail. Consider example (16) from above again, repeated here as (36):

(36) [Mielótt Péter elment otthonról], megnézte a postáját. what-Before Péter left home checked the mail-his-ACC 'Before Péter left home, he checked his mail.'

If we were to provide the same analysis to this temporal clause that we also provided for since-type clauses, we would run into trouble. Relativizing a before time expresion (as shown in $37 \mathrm{a}, \mathrm{b}$ ) and applying the resulting free relative to the main event would give the wrong meaning $(37 \mathrm{c})$ :
a. [ip he left home $\underline{t}$-BEFORE]
b. [CP REL-wh-BEFORE $\left[\right.$ [IP he left home $\left.e_{i} \quad\right]$ ]
c. '\#the time before which Péter left (he checked mail)'

In other words, before does not originate from inside the temporal clause, unlike until/since/when-phrases, which modify the event in the relative clause. This simple meaning consideration then accounts for the fact that before/afterclauses in Hungarian do not have an ordinary relative clause structure.

While this explanation clearly accounts for the distinct behaviour of beforeand after-clauses, the explanation however, does not extend to the whole range of before-type temporals Hungarian. The other two members of this group, mialatt 'what-IN' and miközben 'what-DURING' clauses cannot be said to have a similar meaning to before/after in this respect. These have an interpretation that runs parallel to since-clauses to the extent that the postpositional whphrases originate from inside the temporal clause. Consider (19) from above, repeated here:

(38) [Miközben Anna vásárolt], Péter megnézte a postáját. what-DURING Anna shopped Péter checked the mail-his-ACC 'While Anna was shopping, Péter checked his mail.' 
The intepretation of such a temporal clause can run perfectly parallel to sinceclauses (see previous section). Hypothesing the movement of a during-phrase in a relative clause structure clearly gives rise to the proper interpretation:

[IP Anna shopped $\underline{t}$-DURING]

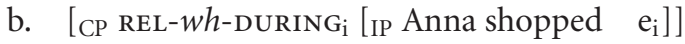

c. 'the time during which Anna was shopping, Péter checked his mail'

Nevertheless, the fact that miközben/mialatt 'what-DURING/what-IN' are systematically different from since-type temporals in their syntax indicates that they do not take part in a structure like (39). The question then is, what blocks this derivation? The answer lies in an idiosyncretic property of közben and alatt. These postpositions do not have a question word variant corresponding to time expressions. The phenomenon will be illustrated with közben 'DURING'.

First, note that the $w h$-word asking for a temporal argument is $m i$ 'what' in Hungarian. This can be seen from the fact that run of the mill temporal expressions like when, since when, until when use mi- 'what' or its allomorph me- 'what'. Mi/me- asks for the default temporal argument, a point in time. Examples are provided in (40).
a. Mikor ment el Péter?
(answer: At noon.) what-AT left PV Péter 'When did Péter leave?'
b. Mikorra ért oda Péter?
(answer: At noon.) what-AT got PV Péter 'By when did Péter get there?'
c. Mióta van itt Péter? what-SINCE is here Péter 'Since when is Péter here?'
(answer: Since noon.)
d. Meddig maradt Péter? what-TILL/whiLe stayed Péter 'Till when did Péter stay?'
(answer: Till noon.)

Second, the postposition közben 'during' can only combine with event nominals (i.e. those with a temporal argument), but not with any other time expression, be that either a temporal measure phrase or a referential temporal expression like 'holnap 'tomorrow': 11
a. az előadás közben
b. ${ }^{*}$ öt óra közben
c. ${ }^{\star}$ holnap közben the lecture DURING five hour DURING tomorrow DURING 'during the lecture' 'in five ours' 'during tomorrow' 
Since közben cannot combine with any kind of referential time expression, it does not come as a surprise that it cannot combine with the default wh-time expression, $m i$ ' what', either:

(42) ${ }^{\star}$ Miközben ment ki Péter? what-DURING went PV Péter 'During which time period did Péter leave?'

The string in (42) can only be grammatical if the reference of $m i$ 'what' is explicitely provided by the discourse, by naming events. Note that in this case $m i$ refers to these events, which in the following example are denoted by the nominals elóadás 'lecture' or vita 'discussion':

(43) Mi közben ment ki Péter? Az elóadás közben vagy a what DURING went out Péter the lecture DURING or the vita közben?

discussion DURING

'During what did Péter leave?' During the lecture of during the discussion?'

In (43) $m i$ 'what' refers not to a default time expression, but asks for one of the events provided by the nominals in the second sentence of the discourse. ${ }^{12}$

The same restrictions carry over to alatt 'IN': this postposition can only take a restricted set of nominal complements, too, ${ }^{13}$ and just like közben, this postposition cannot show up with a $w h$-phrase refering to a default temporal time expression (cf. 42). Supplying explicit events as in (43) is possible with alatt, as well, though.

The pattern in (42)-(43) moreover fully carries over in exactly the same way to before/after as well, the other two members of the before-group. Observe (44) and (45): ${ }^{14}$

$(44) \times$
${ }^{*}$ Miután/mielőtt
ment ki Péter?
what-AFTER/what-BEFore went PV Péter
'After/before what time did Péter leave? (answer: After/before 5 o'clock.)

(45) Mi után/előtt ment ki Péter?

what AFTER/BEFORE went PV Péter

Az előadás után/előtt vagy a vita után/elótt?

the lecture AFTER/BEFORE or the discussion AFTER/BEFORE

'After/before what did Péter leave?' After/before the lecture or the discussion? 
Coming back to the structure of temporal clauses, with the above facts in place, we easily arrive at the right generalization about the distribution of since-type and before-type temporal $w h$-phrases. All we have to do is list which items can occur in an ordinary wh-question about times:

Table 3. The correspondence between temporal wh-expressions and temporal whwords

\begin{tabular}{lllll}
\hline & wh-phrase & & $\begin{array}{l}\text { corresponding } \\
\text { temporal question }\end{array}$ & example \\
\hline \multirow{4}{*}{ since-group } & (a)mikor & REL-what-AT & $\checkmark$ & $(40 \mathrm{a})$ \\
& (a)mikorra & REL-what-AT-BY & $\checkmark$ & $(40 \mathrm{~b})$ \\
& (a)mióta & REL-what-SINCE & $\checkmark$ & $(40 \mathrm{c})$ \\
& ameddig & REL-what-WHILE & $\checkmark$ & $(40 \mathrm{~d})$ \\
& mielőtt & what-BEFORE & $*$ & $(44)$ \\
before-group & miután & what-AFTER & $*$ & $(44)$ \\
& mialatt & what-IN & $*$ & $(\mathrm{fn} .13)$ \\
& miközben & what-DURING & $*$ & $(42)$ \\
\hline
\end{tabular}

From Table 3 it is easy to see now what differentiates the two groups of wh-items. The two groups differ sharply in whether they can figure in normal questions: the since-group can, while the before-group cannot.

With this in mind let us come back to the question posed in the beginning of this section: why is it the case that the before-group does not take part in a relative clause structure, which the since-group employs? To put it in more detailed structural terms, why is it that the structure in (46) is not available to temporal clauses with mielött 'what-BEFORE', miután 'what-AFTER', mialatt 'what-IN', and miközben 'what-DURING'?
a. [IP he left home $\underline{t}-\mathrm{P}$ ]
b. [CP REL- $w h_{\mathrm{i}}-\mathrm{P}$ [IP he left home $\mathrm{e}_{\mathrm{i}}$ ]]

The answer can be read off from Table (3): before-type temporals do not have the relativization structure involving the movement of a temporal whexpression, because before-type wh-expressions are not available as question words in Hungarian. No member of the before-group of $w h$-items can appear in questions about times. Under the commonly held view that relativization is wh-movement (Chomsky 1977), the lack of such wh-expressions immediately explains why the corresponding relative clauses do not exist, either. The structure in (46) moreover is also ruled out with empty operator movement as well, 
due to the independent reason that Hungarian relative clauses never feature empty operators.

So, in sum, there is no way of deriving a structure like (46) in Hungarian with postpositions of the before-type, as these postpositions do not combine with $w$ h-items (or empty operators) to yield temporal question words in this language. Why exactly these $w h$-items are impossible in questions is a very interesting puzzle that would merit research on its own. The fact that some $w h$-items or $w h$-phrases are missing in a language is to a large extent an idiosyncratic property of the lexicon of the language. Syntax can only handle lexical items that are available to it. Those question words that are missing in the lexicon result in gaps in the paradigm of clausal constructions as well. In our case this means that before/after/in/while clauses in Hungarian thus cannot take part in an ordinary relativization strategy. They are not ordinary relative clauses. What remains to be seen still is what strategy they involve then. This is what we turn to in the next section.

\section{The structure of before-type temporals: IP-relativization}

The conclusion of the previous section was that before-type temporal clauses are not ordinary relative clauses. While this is an unavoidable conclusion we have to draw on the basis of our data, it presents us with a puzzle: if these clauses are not relative clauses, how come they feature a $w h$-item? This is the more puzzling because these structures do not lend themselves to any alternative analysis that could explain the presence of these wh-items. For one, these clauses clearly cannot instantiate any other clause type. Although wh-phrases can occur in questions and exclamatives, temporal clauses are neither questions nor exclamatives for obvious reasons.

There is however, a very simple way out of the puzzle. All we need to do is assume that although before-type temporals are not relative clauses of the standard sort, they are relative clauses of some type nevertheless. They differ from standard relatives exactly in the most crucial ingredient of relativization: the size of the relative operator. Unlike ordinary relativization where a temporal wh-phrase undergoes movement, in before-type temporal clauses it is a larger constituent that moves. A constituent that is not a temporal modifier but which does have temporal specification: a finite IP. The present section explores this idea at length and shows that such an analysis is indeed a viable treatment, 
which can also explain the observed properties of these clauses without further assumptions.

3.1 The internal structure of IP-relatives

Consider the contrast between (42) and (43) again, from above:

$(47){ }^{*}$ Miközben ment ki Péter?

what-DURING went PV Péter

lit. 'During which time period did Péter leave?'

(48) Mi közben ment ki Péter? Az elóadás közben vagy a what DURING went Pv Péter the lecture DURING or the vita közben?

discussion DURING

'During what did Péter leave?' During the lecture of during the lunch?'

This pair illustrated that while miközben 'what-DURING' does not exist as a temporal expression asking for a time (cf. 47), the phrase mi közben 'what-DURING' can stand for events (cf. 48). Taking this as our lead, let us assume that the wh-phrase mi 'what' in miközben 'what-DURING' in a temporal clause does the same: it does not stand for a temporal modifier of an event, but for the whole event denoted by the IP. In this analysis, a sentence like (49) can be paraphrased in the following manner:

(49) [Miközben Anna vásárolt], Péter megnézte a postáját. what-DURING Anna shopped Péter checked the mail-his-ACC lit. 'During what was (the event of) Anna shopping, Péter checked mail.'

Taking this paraphrase as our lead, it is possible to design a structural analysis that provides the $w h$-item $m i$ with the content of the IP, retaining the idea that the temporal clause is a relative clause. This goal can be easily achieved by adopting a structure that is inspired by the head-raising analysis of relativization (Kayne 1994). To relate $m i$ to the IP in the spirit of this account, all we have to say is that $m i$ is a relative determiner that takes an IP as its complement. ${ }^{15}$ In this respect $m i$ is fully parallel to standard relative determiners (like which), which take NP complements, but it differs from those in the category of the complement it takes.

This way, the underlying structure of before-type temporals can be made fully parallel to ordinary free relatives, like the string what money I had (on the derivation of the latter, see Kayne 1994:154, fn. 13). Compare first the 
structure of the relative phrase in ordinary relative clauses and in our temporal IP-relatives:

(50) a. [RelP [Rel' what [NP money ] ]]

ordinary NP relative

b. [RelP [Rel' mi [IP Anna vásárolt]]]

IP-relative

what Anna shopped

The relative phrase in the case of IP-relativization contains a clausal constituent: a whole IP, corresponding to the usual NP lexical constituent found in ordinary relatives. (50b) furthermore nicely accommodates the event-related nature of the mi relative pronominal, which was pointed out above. This structure also makes the right predictions when it comes to the restrictions we find with respect to the category of the relativized constituent. Given that the relative pronoun in the Kaynean raising analysis is a determiner, it cannot take DP complements. In ordinary relatives, the relative determiner always selects an NP, not a DP. This restriction should have a parallel in the clausal domain as well: if $m i$ functions as a relative determiner, we expect that it can only take clauses that are non-determined. In the clausal domain, CPs corresponds to DPs in the nominal domain, and IPs (TPs) correspond to NPs (Szabolcsi 1992; Tsoulas 1995). As expected, this is indeed what we find: $m i$ is always complemented with an IP in temporal clauses. These clauses do not feature any complementizer, in any position:

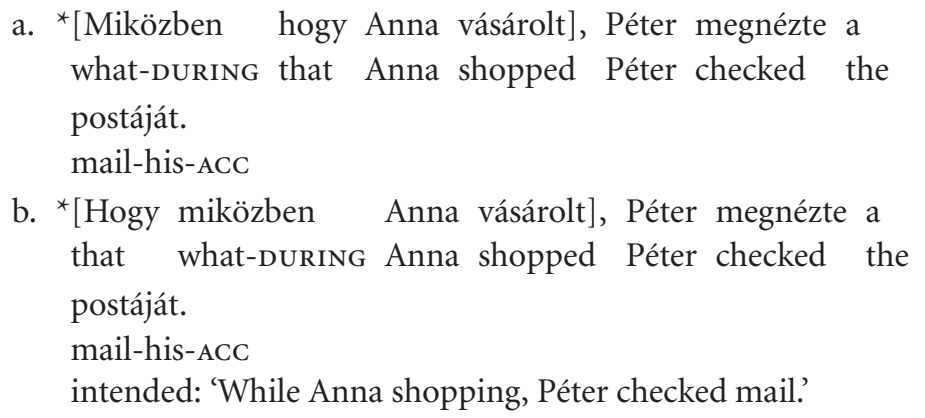

After establishing the base structure of the relative clause, let us proceed to establish further steps of the derivation of the temporal clause. In ordinary relatives the next step in the derivation is the fronting of the whole RelP to Spec,CP. This steps places the relative phrase into sentence initial position:

(52) $[\mathrm{CP}[$ RelP [Rel' what [NP money $]]]_{\mathrm{i}}\left[\mathrm{IP}\right.$ I had t $\left.\left.\mathrm{t}_{\mathrm{i}}\right]\right]$ 
In the case of IP-relativization, we can also find a $\mathrm{CP}$ that is erected on top of the RelP. This is necessary to provide the RelP structure with a clausal status. Unlike in ordinary free relatives, however, we do not have evidence for the movement of the RelP to the specifier of CP. This movement step is completely vacuous, as there is nothing that precedes the relative phrase in the clause. Assuming that vacuous movement is not part of natural language (in the spirit of, among others, Grimshaw 1997), I take it that there is no movement taking place to Spec,CP. The structure we get is (53):

$$
\text { [CP [RelP [Rel' mi [IP Anna vásárolt ]]]] }
$$

The last step in the derivation is the merger of an external $\mathrm{D}^{0}$ head to the $\mathrm{CP}$, which builds a DP layer. This is necessary because the whole structure will be fed to a postposition, and these in Hungarian cannot select CPs:

(54) [DP [CP [RelP [Rel' mi [IP Anna vásárolt ]]]]]

The DP that is projected this way can then serve as the complement of the postposition that merges with the relative clause from the outside:

(55) [PP közben [DP [CP [RelP [Rel' mi [IP Anna vásárolt ]]]]]]

After this structure has been built, there is one movement step that is still required. This is due to the independent property of Hungarian postpositions that they require a nominal to their left. What element undergoes raising in our cases? Although the complement of the postposition is a nominal phrase externally (a DP), the whole DP cannot move to P because postpositions never combine with clausal material in Hungarian. This rules out the movement of the whole DP complement. Instead, it is the nominal relative determiner mi that raises up to P. This movement step gives us the surface word order of a temporal clause: wh-P-IP. Mi-movement is thus triggered by the needs of the postposition. I believe furthermore that this overt movement step of $m i$ is an instance of head-movement. And as such, it observes the Head Movement Constraint: the moving $m i$ adjoins to the intermediate $\mathrm{C}^{0}$ and $\mathrm{D}^{0}$ heads on its way to $\mathrm{P}$. The movement steps are indicated in (56):

(56) $\left[{ }_{\mathrm{PP}} \mathrm{mi}_{\mathrm{k}}-\mathrm{közben}\left[\mathrm{DP} \mathrm{t}_{\mathrm{k}}\left[\mathrm{CP}_{\mathrm{k}} \mathrm{t}_{\mathrm{k}}\left[\operatorname{RelP}\left[\mathrm{Rel}^{\prime} \mathrm{t}_{\mathrm{k}}\right.\right.\right.\right.\right.$ [IP Anna vásárolt ]]]]]]

Externally, the resulting structure is a PP, in which the nominal argument is a free relative clause. Before-type temporal clauses are thus relative clauses embedded under a PP layer. The category specification of these clauses will play an important role in explaining some of the properties of these clauses. 
To illustrate the mechanism of IP-relativization with tree structures, let us take stock of the movement steps of the proposal again. The claim is that in Hungarian temporal clauses of the before-type we find an instance of $I P$ relativization, relativization of functional material. This happens the same way as in other cases of relativization in the head raising analysis of relatives. First a finite clause is projected up to the IP level. When structure building reaches the level of IP, a relative determiner builds on top of the IP, taking the IP as its complement:

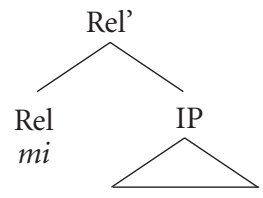

On top of this structure, first a CP, then a DP layer get built. The latter is then taken as complement to the postposition. The requirements of the postposition force the movement of the nominal $m i$ in overt syntax, up to the postposition, in a manner illustrated in (58).

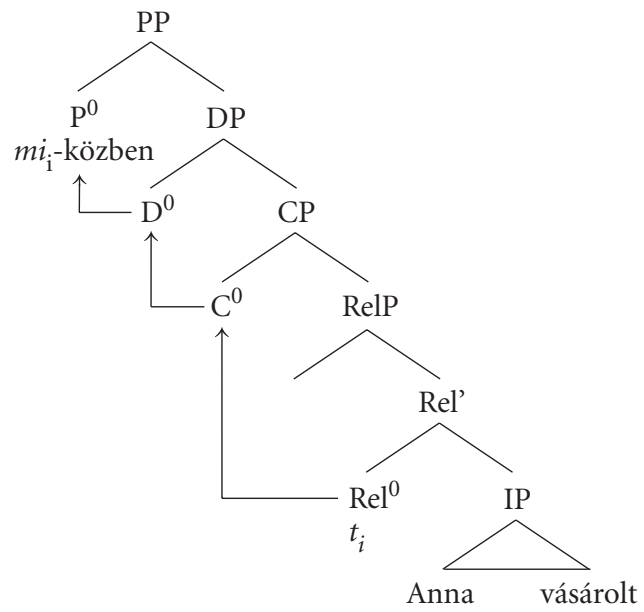

The only ingredient of the proposed analysis that differs from well-known instances of relativization is the size of structure that is relativized. Ordinary relativization involves relativization of lexical categories (NPs or APs). Our temporal clauses however, relativize a whole clause, an IP constituent, which is the projection of a functional category. This however, need not shock us: relativization of clausal material is not unknown. VPs or whole clauses can be relativized 
in so-called clausal (non-restrictive) relativization. The properties of these relative clauses will be listed in Section 3.3 below. Before turning to this, the next section will demonstrate how the proposed analysis explains the properties of before-temporal clauses that were observed in Section 2.2.

\subsection{The syntactic properties of before-type temporal clauses explained}

The previous section provided an analysis for before-type temporals in terms of IP-relativization. This was summarized in the structure in (58). In this section we return to the syntactic properties of these temporal clauses to show that the proposed analysis can account for these without problems.

The properties to be accounted for are the following (see Section 2.2 for full illustrations):

(i) before-type temporals do not combine with noun phrases

(ii) before-type temporals cannot have multiple $w$ h-pronouns

(iii) before-type temporals do not allow for low readings

The first property concerns the fact that before-clauses are never found modifying nominal phrases. See (59), repeated from above:
a. ${ }^{\star A}$ nap [miután Anna megjött ] emlékezetes Péternek. the day what-After Anna arrived memorable Péter-DAT 'The day when Anna arrived is memorable for Péter.'
b. ${ }^{\star A}$ nap után [miután Anna megjött ] Péter boldog volt. the day AFter what-After Anna arrived Péter happy was 'After the day when Anna arrived Péter was happy.'

The explanation for this is very simple. As we see in this structure, the temporal clause is a postpositional phrase externally. This $\mathrm{PP}$ contains a relative clause inside, but this is not visible from the outside. The temporal clause is categorically different from a relative clause externally. Since the temporal clause is not a relative clause, we expect that it cannot modify nominals. This is in line with the observed data in (59).

The second property concerns the restriction on multiple relative pronouns. Consider (60) repeated from above:
(60) $*[\mathrm{Ki}$ mialatt énekel $]$, az akkor boldog. who what-IN sings that that-AT happy 'Everyone is happy when he/she is singing.'


The explanation for this behaviour can also be read off from the structure in (58). Since the relative determiner $m i$ 'what' is a determiner that selects the whole IP as its complement, there cannot be any other argument phrase that can also undergo relativization. There is no element left outside the IP that could be relativized next to the IP.

The third characteristic property of before-type clauses is the lack of low readings in complex structures. If the temporal clause contains embedding, the low reading in which the temporal wh-phrase is linked to the embedded clause is systematically missing:

(61) Azután indulok el [miután szólsz [hogy Péter elindult]]. that-AfTer leave-1sg Pv what-AfTer tell-1sg that Péter left-3sG high: 'I leave after time $t$ when you tell me that Péter has left.' *low: 'I leave after time t. You tell me that Péter left at time t.'

This is in sharp contrast to English before/after-clauses, which do allow for a low reading (Larson 1988):

(62) a. I will leave before you said that Peter left.

high: 'I leave before time $\mathrm{t}$ when you tell me that Péter has left.' low: 'I leave before time t. You say that Péter left at time t.'

b. I will leave after you said that Peter left. high: 'I leave after time t when you tell me that Péter has left.' low: 'I leave after time t. You say that Péter left at time t.'

The reason why Hungarian before-type clauses lack low readings while English before-clauses have it follows from the fact that they have a different underlying syntax. The lack of low readings in Hungarian before-type clauses is due to their internal composition again. As we showed, Hungarian before-clauses involve IP-relativization: there is a relative clause built onto a RelP that contains an IP. For a low reading to be present, this RelP must undergo a long (i.e. crossclausal) wh-movement step. In other word, the following movement step has to take place: 
(63)

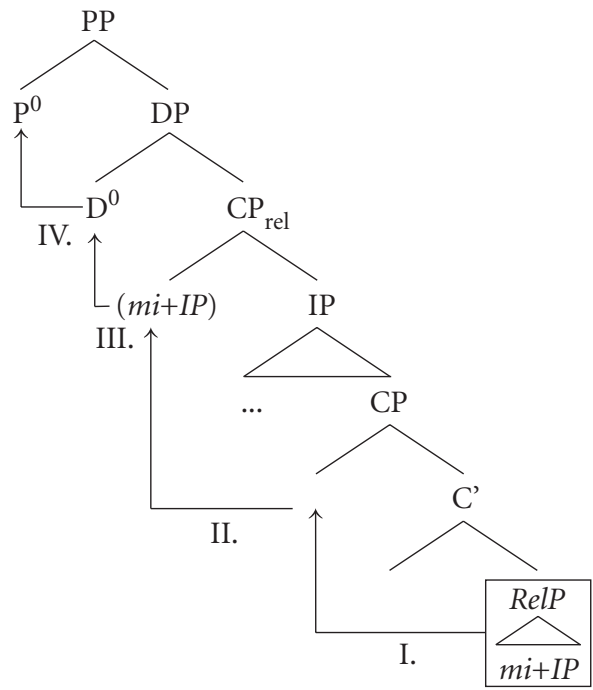

In this hypothetical structure, the RelP is generated in the embedded clause, and then moves up, through the embedded Sp,CP to the higher, relative $\mathrm{CP}$. From this point on, $m i$ then has to raise out to the $\mathrm{P}$ head (illustrated with dashes). This derivation, however, violates the ECP. The problematic step is step I. The trace that would be left behind by the moving RelP constituent is not properly governed. It is not (head-) governed by $\mathrm{C}^{0}$, since complementizers are not proper (head)-governors, and it is not antecedent governed from the higher clause either, because the embedded $\mathrm{C}^{0}$ sets up a minimality barrier. Since step I cannot take place for this reason, the RelP cannot reach the relative $\mathrm{CP}$. Due to this, mi cannot adjoin to $\mathrm{P}$ either. Long distance headmovement of this item from its base position would also be ruled out by the HMC. This explains why complex temporal clauses can never give rise to a reading in Hungarian in which the relativized constituent is the embedded IP.

The high reading is available in these sentences, since relativizing the higher IP (that in the higher clause) is not problematic at all. The derivation in this case proceeds exactly as it does in simplex clauses (compare (58)), except that the RelP now contains a complex IP. 
(64)

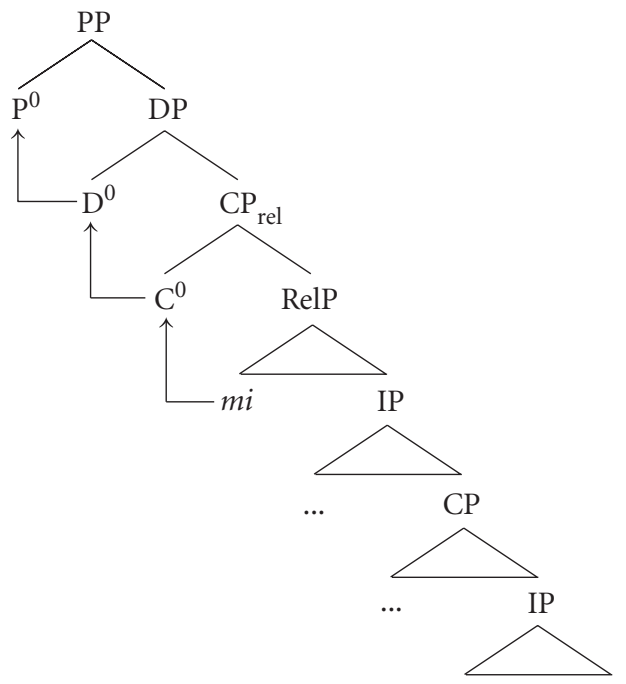

The above explanation, which crucially builds on the impossibility of moving the RelP constituent out of its base-position in (63), provides us with a very important insight to the nature of IP-relatives. Given that RelP cannot undergo movement, due to an ECP violation, IP relativization is expected to always keep the relativized constituent in-situ. In other words, IP-relatives are necessarily internally headed relatives.

Summing up the results of this section, it seems that the IP-relativization analysis of before-type temporals, and the proposed structure in (58) can successfully account for the observed properties of before-clauses without any auxiliary assumptions. Unlike since-type temporals, before-type clauses cannot modify nominals, cannot contain multiple wh-expressions and cannot have low distance construals. As we showed, these properties follows from the ingredients of our analysis. The first two properties follow from the fact that the temporal clause is a PP externally and not a relative clause. The last property follows from the fact that IP-relativization never gives rise to the movement of the relative phrase. IP-relatives are necessarily internally headed relatives.

\subsection{A note on clausal (non-restrictive) relatives}

The previous two sections put forward the claim that before-type temporal clauses in Hungarian contain an IP-relative, embedded under a PP layer. The novelty of this proposal concerns the nature of the relativized constituent: a 
clausal functional projection. While this might sound strange at first sight, it is not at all strange if we consider the fact that relativization of clausal constituents is well-attested across languages. This section will illustrate this frequently occurring type and compare its structure to the proposed structure of IP-relativization. The purpose of this section is to point out that the newly discovered IP-relativization differs from this well-attested type of clausal relativization, although it shares some characteristics with it. This exercise will also serve another purpose: the comparison between the two types of clausal relativization structures will provide us with a possible handle on the morphological appearance of before-type clauses concerning $a$ - marking (see Section 2 above).

Clausal relativization structures are known in the domain of appositive relativization. So-called clausal non-restrictive relatives (Potts 2002a, b) relativize a clausal constituent, too. Staying with Hungarian for sake of illustration, consider the following examples:
a. Egbert beteg, ami sajnálatos dolog.
Egbert sick REL-what unfortunate thing
'Egbert is sick, which is unfortunate.'
b. Tamás megjött, ami után Zsuzsa elment.
Tamás arrived REL-what AFTER Zsuzsa left
'Tamás arrived, after which Zsuzsa left.'
c. Tamás megjött, ami miatt Zsuzsa elment.
Tamás arrived REL-what BeCAuse Zsuzsa left
'Tamás arrived, because of which Zsuzsa left.'

Just like the IP-relativization in temporal clauses, clausal appositive relatives also cast restriction on the size of the relativized material in them. Only IPs can be relativized, CPs are systematically excluded: ${ }^{16}$
(66) ${ }^{*}[$ Hogy Egbert beteg], ami sajnálatos dolog. that Egbert sick REL-what unfortunate thing 'Egbert is sick, which is unfortunate.'

This is the same that we also find in Hungarian before-temporals: the clausal part of the structure following the $w h$-phrase involves an IP only, but never a CP (see example (51) above). This suggests that IP-relatives and clausal appositive relatives have something in common syntactically. The fact that clausal relatives also use the same relative pronoun, $m i$ 'what' reinforces this point. 
At the same time, it is very clear that clausal relatives and IP-relatives are not the same in every respect. The most conspicuous evidence for this comes from the morphological composition of the relative pronoun in the two cases: as we have seen, in temporal IP-relatives, the $w h$-item is always bare: before-type $w h$-items do not bear the relative $a$ - marker. Clausal relatives like (65), however, are obligatorily adorned with this item. In this they pattern with standard relativization, which, apart from the relative pronoun mely 'which' always uses the $a$ - marker (cf. 20). The obvious question to ask is, why is there such a difference between the two constituent types? If clausal relatives in (65) also involve IP-relativization, according to the testimony of (66), should they not show the same morphology as well?

Morphological properties reflect syntactic properties in this case, too. There are two important syntactic differences between IP-relatives and clausal appositive relatives. The first is that IP-relatives contain the relativized IP internal to the relative $\mathrm{CP}$, while clausal relatives have the relativized clause outside of the relative CP. The second difference has to do with interpretation: clausal relatives are appositive relatives. The relative clause following the relativized clause is of parenthetical or afterthought nature. The IP-relativization that we uncovered in temporal clauses on the other hand presumably does not qualify as a non-restrictive clause. Although the usual tests of restrictiveness cannot be applied to these constructions (as the relativized IP has independent reference on its own: it denotes an event), the relative clause does not have appositive intonation and parenthetical or afterthought interpretation.

For these reasons the structure of clausal appositives is different from IPrelatives. Clausal appositives have been recently analyzed by Potts (2002a, b) and de Vries (to appear). Both argue independently of each other that clausal relatives involve traces that are individual denoting (i.e. nominalized propositions). For the particular structural representation of these, I borrow de Vries' representation, which is couched in the head raising framework. In this account, appositive relatives are coordinated to the head they modify. The relativized constituent is base-generated in the specifier of the coordination phrase, while the complement of this phrase contains the appositive relative clause. The latter is assumed to be a pronominally headed relative, where the pronominal spells out the relative $\mathrm{D}$ head into which $\mathrm{N}$ raising has taken place. The whole structure is represented in (67). 
(67)

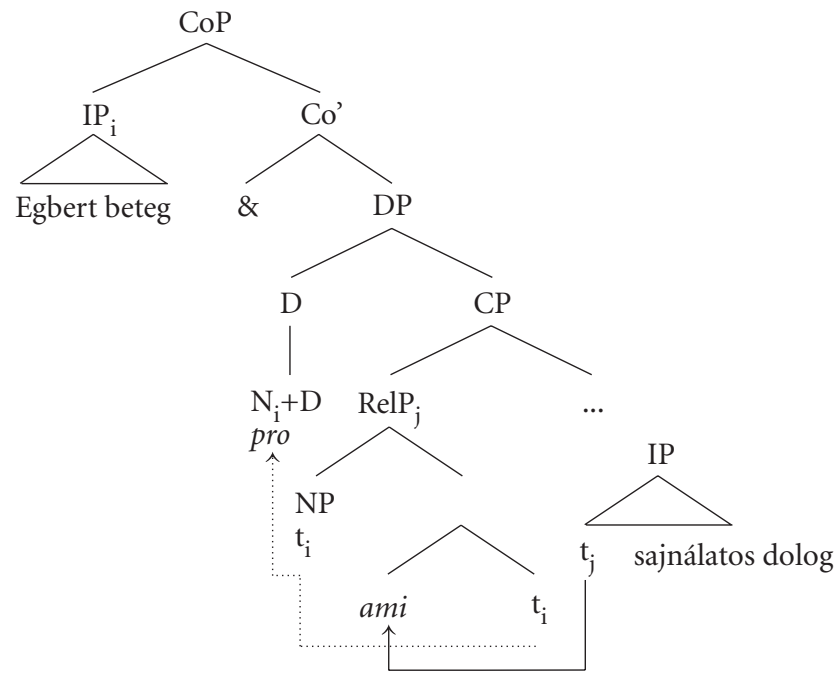

De Vries (to appear) motivates the presence of the pronominal head (the spellout of the $\mathrm{N}+\mathrm{D}$ complex) by the observation that in some cases of appositive relativization such pronominals can be overt in some languages. The case he quotes is VP relatives in French (Canac-Marquis \& Tremblay 1998). Notice the demonstrative pronoun $c e$ 'that' preceding the relative:

(68) Marcelle est très fatiguée, ce que Marie n'est pas. Marcelle is very tired that REL Marie NEG is not 'Marcelle is very tired, (something) which Marie is not.'

It has to be noticed that such a pronoun is also found in sentential relatives, like in the following example:

(69) Jean est malade, ce qui est étrange. Jean is sick that REL is strange 'John is sick, which is strange.'

This gives support to the representation in (67).

Now, with this analysis in place, we can return to the problem of morphology. Why do clausal relatives show $a$ - marking while IP-relatives in temporal clauses do not? The structural representations of the two structures offer an explanation for this difference. Compare the representation of (67) with our analysis of IP-relativization from (58), repeated here: 
(70)

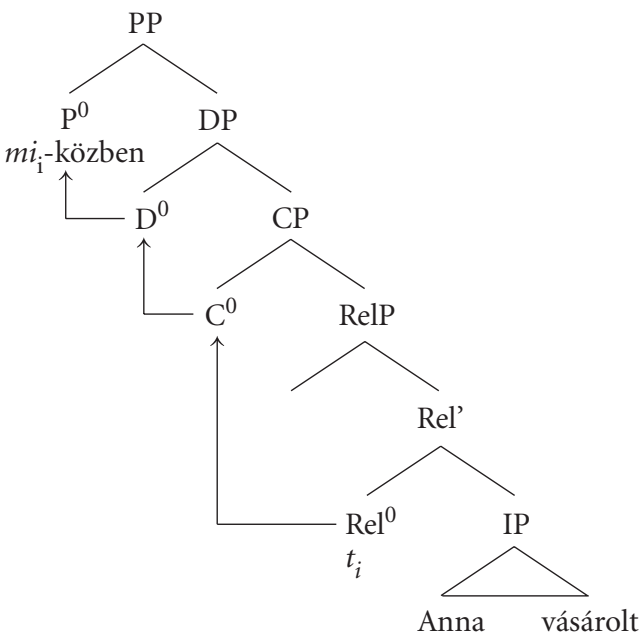

We can derive the morphological difference by exploiting the structural difference between the two constructions, more specifically the IP vs. NP category difference when it comes to the complement of the relative pronominal in the two cases. In temporals, the relative pronoun takes an IP. As the present section showed there are arguments to the effect that in appositives this is never the case: the relativized IP does not originate from inside the relative. Rather, it is represented there by an abstract noun. The relative determiner takes a noun as its complement, not an IP. This means that sentential relatives are nominal relatives in fact.

It is conceivable then that the morphological difference in Hungarian mirrors this category difference: relative pronouns are only adorned with $a$ - when they take lexical complements (NP, AP), but lack $a$ - when they take functional ones (IP). This means that sentential relatives have the morphology of ordinary nominal relatives as they are in fact ordinary nominal relatives when it comes to the composition of the RelP. Ordinary relatives in Hungarian obligatorily show $a$ - marking, and so do sentential relatives which use the structure of nominal relatives as well. Before-type temporal clauses on the other hand do not show $a$ - marking as in these clauses the relative pronoun takes an IP (a non-lexical structure) as complement. This provides a neat account for the lack of $a$-marking on before-type $w h$-expressions.

In this respect it needs to be mentioned that since-type temporal clauses show an optional $a$-marking (recall the facts in Section 2.1 above) - the ac- 
count presented here does not cover these facts. I leave the optionality of the $a$ element in these cases for further research.

\subsection{Interim summary}

The present section argued that before-type temporal clauses in Hungarian have the structure of a relative clause in which the finite IP is the relativized constituent. Before-type clauses contain a relative clause, which explains why they feature a $w h$-item. The relative clause that results after IP-relativization is furthermore embedded under a DP and PP layer in these temporal clauses. This means that externally, these clauses are not run-of-the-mill relatives, which dovetails with their syntactic behaviour: they do not show properties of ordinary relatives.

Crucially for the purposes of syntactic analysis, the proposed IP-relativization strategy is not the same as clausal appositive relativization. While both involve relativization of clausal material, the latter is an ordinary nominal relativization process, while the former is not.

\section{IP-relativization in German and Serbian}

As Section 2.4 spelled out, the prepositions before/after cannot originate from within the temporal clause, for reasons having to do with their meaning: the before/after-phrase does not modify the subordinate VP. Section 3 showed that an alternative relativization strategy that can be used with before/after-clauses is one that relativizes the whole subordinate event.

This section tries to show that the IP-relativization strategy that underlies Hungarian before-type clauses is most probably also available in other languages as well. Two cases will be mentioned which easily lend themselves to an IP-relative analysis: after-, while- and since-clauses in German and after-clauses in Serbian. The purpose of this chapter is to merely sketch an IP-relativization analysis for these clauses, offering only tentative results. 
4.1 German temporal clauses with nachdem 'AFTER', indem 'WHILE' and seitdem 'SINCE' 17

Consider the following temporal clauses in German:
a. John fuhr
ab bevor Bill ankam.
before-clause
John departed Pv before Bill PV-arrived
'John departed before Bill arrived.'
b. John fuhr ab nachdem Bill ankam.
after-clause
John departed PV after-dem Bill PV-arrived 'John departed after Bill arrived.'
John departed PV in-dem Bill PV-arrived
'John departed while Bill arrived.'
c. John fuhr ab indem Bill ankam.
while-clause
d. John hat keine Zeit seit(dem) er arbeitet. since-clause
John has no time since-dem he works
'John has no time since he works.'

While the before-clause in (71a) shows great similarity to English before-clauses in that it features a prepositional item bevor followed by an IP, the after-, whileand since-clauses in $(71 \mathrm{~b}, \mathrm{c}, \mathrm{d})$ are more complex than that. They contain an element composed of a preposition followed by dem. The latter dem element is formally identical to a dative marked masculine/neuter demonstrative pronoun. What is the role of this element?

First, it has to be noted that this pronoun is not a complementizer: dem can never be found to introduce finite clauses in German, indicating that German after-clauses are not finite complement clauses. Dative marked dem occurs in two contexts with prepositions in German. In one, it acts as a definite determiner in a PP introduced by a dative case assigning preposition (72), in the other it is a relative pronominal in a PP (73):
a. Er furh he departed PV to the south 'He departed to the south.'
b. Er wohnt in dem Süden. he lives in the south 'He lives in the south.'

ab nach dem Süden.

dem as a determiner
a. das Dorf nach dem er abfuhr the village to which he pv-left 'the village to which he departed' 


\section{b. das Dorf in dem er wohnt the village in which he lives 'the village in which he lives'}

It is easy to show with the help of contraction facts that the dem that occurs in temporal clauses is not the definite determiner that shows up in the examples in (72). As it is well-known, the definite determiner can be contracted onto certain prepositions, like in, as (74) shows:

(74) Er wohnt im Süden.

he lives in-the south

'He lives in the south.'

Relative pronouns on the other hand cannot be contracted in the same way:

$$
\begin{aligned}
& \text { (75) *das Dorf im er wohnt } \\
& \text { the village in-which he lives } \\
& \text { 'the village in which he lives' }
\end{aligned}
$$

This behaviour runs parallel to what we find in temporal clauses, where such contraction is also ungrammatical:

(76) ${ }^{\star}$ John fuhr ab im Bill ankam.

John departed PV im Bill PV-arrived

'John departed while Bill arrived.'

These contraction facts show that dem in temporal clauses is a relative pronoun, and not a determiner. ${ }^{18}$

Knowing that these temporal clauses are relative clauses in fact lead us to the next question: what exactly is relativized in them? The relativized constituent cannot be a temporal $w h$-phrase, because these use the relative pronoun wenn 'when', and not dem:

(77) Wenn er keine Zeit hat, schläft er nicht. when he no time has sleeps he not 'When he does not have time, he does not sleep.'

Therefore it cannot be the case that nachdem-type clauses involve a covert wenn-strategy, since this would wrongly predict the use of dem in them. It is also equally unlikely that nachdem-clauses involve an abstract head referring to time, as in (78) for example: 
(78) John fuhr ab nach (der Zeitpunkt) John departed PV after the timepoint $[$ dem .... $]$ which-DAT 'John departed after the time when ...'

This solution suffers from the problem that overt time expressions in structures like (78) do not use relative pronouns but relative complementizers like als lit. 'than' and wo lit. 'where' (referring generally to time and place respectively):

(79) a. der Zeitpunkt als/wo Bill ankam the timepoint than/where Bill $\mathrm{PV}$-arrived

b. die Zeit als/wo Bill ankam the time than/where Bill Pv-arrived 'the time when Bill arrived'

This rules out (78) as a possible structure for nachdem clauses as well.

Since other options are ruled out, we are left with the suspicion that German $P+d e m$-temporal clauses involve relativization of material that is not a temporal expression, but a larger constituent. Taking the lead of the analysis of the Hungarian facts from the previous sections, this constituent can be the whole IP. According to the IP-relativization analysis, dem selects the subordinate IP as its complement. Applying the structure of IP-relativization to temporal clauses with dem, we end up with the structure in (68):

$(80)$

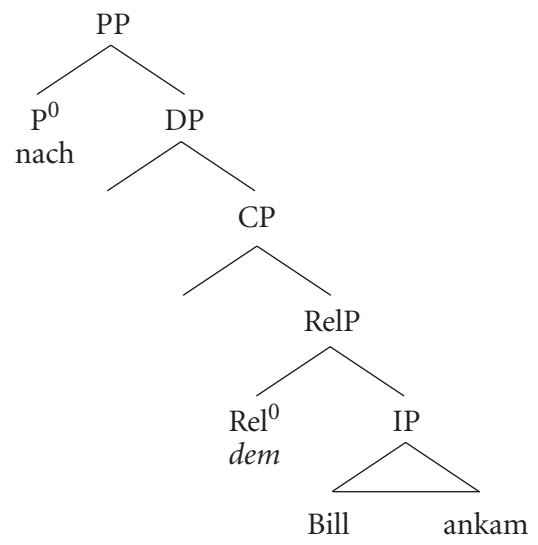

Unlike in Hungarian, the preposition nach does not require anything to its left, so the relative pronoun dem does not have to undergo any further movements 
in (80). With this derivation the word order facts are straightforwardly obtained, and dem 'which' is suitably accommodated as a relative determiner, too.

Admittedly, the details of the IP-relativization analysis for German are far less clear than they are for Hungarian.

Before closing the discussion of German nachdem-type clauses, it is important to point out that just like Hungarian before-type clauses, German nachdem-type clauses lack low readings (Larson 1988; Artstein to appear):

(81) Ich ging weg, bevor/nachdem du sagtest, ich müsse

I went PV BEFORE/AFTER-which you said I must weggehen.

PV-leave

'I left before/after you said I must go.'

high: 'I left at the time before/after you said I should.'

low: *'I left at time t. You said I should leave at time t.'

As Larson (1988) argues, the lack of low construal characterizes every type of temporal clauses in German similarly to ordinary relative clauses in general: German forbids long movements of relative pronouns in them. The lack of low reading in (81) therefore arguably is not indicative of IP-relativization per se, unlike in Hungarian, where before-type clauses, and only these among temporal clauses, lack low readings systematically. Whatever the exact source of the low readings is in German, (81) at least does not contradict an analysis in terms of IP-relativization for nachdem-type clauses.

\subsection{Serbian after- and because-clauses}

Another language that seems to employ IP-relativization in the formation of some adjunct clauses is Serbian. Consider the expression of after-temporals, illustrated in (82): ${ }^{19}$

(82) Jovan je kupio knjigu nakon (toga) što je

Jovan AUX-3sg bought book after DEM-GEN $C_{\text {REL }}$ AUX-3sG

krenuo semestar.

started semester

'Jovan bought the book before the semester started.'

The temporal subordinate clause contains a preposition nakon 'after', a casemarked demonstrative 'toga' 'that-GEN' and an invariant relative complemen- 
tizer što (on the latter, see Browne 1986; Szucsich 2003). The exact same structure $(\mathrm{P}+t o+s ̌ t o+\mathrm{IP})$ characterizes adjunct clauses of reason as well:

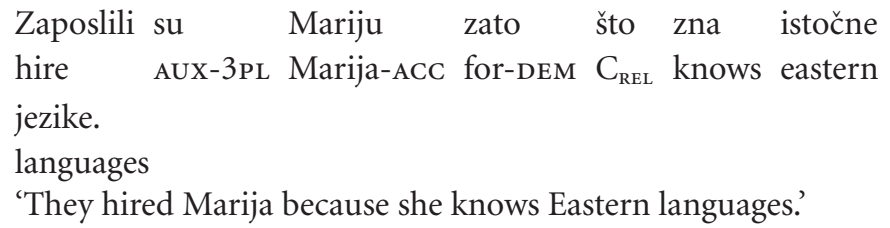

The presence of the relative complementizer što in (82)-(83) unambiguously indicates that the temporal/reason clause has the form of a relative: the complementizer što can occur only in relative clauses and not in finite embedded clauses. Relatives and finite embedded clauses are illustrated in (84) and (85) respectively. Note that the latter use $d a$ as the complementizer: ${ }^{20}$

(84) Jovan je vidio policajca što ga je kaznio. Jovan AUX-3SG seen policeman $\mathrm{C}_{\mathrm{REL}}$ him AUX-3sg fined 'Jovan saw the policeman who fined him.'

(85) Petar veli da sam pisao pismo. Petar says that AUX-1sG wrote letter 'Petar says that I wrote a letter.'

Since the temporal/reason clause is a relative clause, the optional toga 'thatGEN' pronominal found between the preposition nakon 'after' and the relative clause in them has to be the head of the relative clause, occupying the position shown in (86), for after-temporals:

(86) [PP nakon [DP toga [RC što je krenuo semestar ]]]

The need for a nominal like toga is clear: this is the item that receives the case assigned by the preposition (genitive case), instead of the CP, which cannot carry case. It is much less clear though what this pronominal refers to, i.e. what constituent undergoes relativization in these cases.

The default analysis would have it that the relativized element is the temporal adjunct modifier of the embedded VP. This element undergoes covert operator movement, as shown in (87):

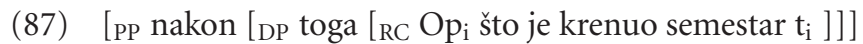

This is the analysis proposed by Citko (2000), for Polish before/after clauses, which feature the exact same elements in the exact same order as Serbian afterclauses. For illustration consider (88): 
(88) Zaśpiewam po tym jak Maria zaśpiewa. (Polish, Citko 2000) sing-1sG after DEM C Maria sings 'I will sing after Maria sings.'

In Polish after-clauses, just as in Serbian, we find a preposition po 'after', followed by a demonstrative tym 'that' and a subordinate clause which is introduced by a complementizer jak 'how' (for more on the latter see Citko 2000). Citko supports the presence of an empty operator that undergoes fronting within the temporal clause (the analysis in (87)) by the observation that Polish before/after-clauses are ambiguous between a low and a high construal when they contain an embedded clause:

(89) Jan odrobil zadanie domowe po tym jak Maria myslala ze Jan did assignment home after DEM C Maria thought that musielismy je oddac.

had-1PL it give

high: 'Jan did the homework assignment after Maria thought that we had to hand it in.'

low: 'Jan did the homework assignment at time t. Maria thought that we had to hand it in at time t.'

As it was argued by Geis (1970) and Larson (1988), the availability of both high and low readings characterizes ordinary relativization and empty operator movement constructions. The structure in (88) is thus evidently the right representation for Polish before/after-clauses which are ambiguous between these two readings.

Serbian, however, does not show such ambiguity with complex sentences. After-clauses only have the high readings (Boban Arsenijević, Radoslava Trnavac p.c.):

(90) Jan je napisao domaci zadatak nakon toga što je Marija Jan AUX wrote home work after that $\mathrm{C}_{\mathrm{REL}}$ AUX Maria mislila da treba da ga predamo. thought hat had that him give 'Jan did the homework assignment after Maria thought that we had to hand it in.'

high: 'Jan did the homework assignment after Maria thought that we had to hand it in.'

low: *'Jan did the homework assignment at time t. Maria thought that we had to hand it in at time t.' 
Note that the unavailability of the low reading in Serbian cannot be due to the fact that the language does not allow for long relativization (as is the case in German for example, see Larson 1988 and the previous section). Long relativization is grammatical in Serbian (Browne \& Alt 2004):

(91) čovek kojeg mislim da ste videli man whom think-1sG that AUX-2sG saw 'the man whom I think you saw'

This shows that (90) lacks the low reading for a reason that is independent of the properties of ordinary relativization in the language. I contend that the explanation for the lack of low readings has to do with the fact that Serbian afterclauses in fact do not involve ordinary relativization, but rather relativization of an IP, as was proposed for Hungarian in this paper.

The structure we get applying the idea of IP-relativization to Serbian afterclauses is (93):

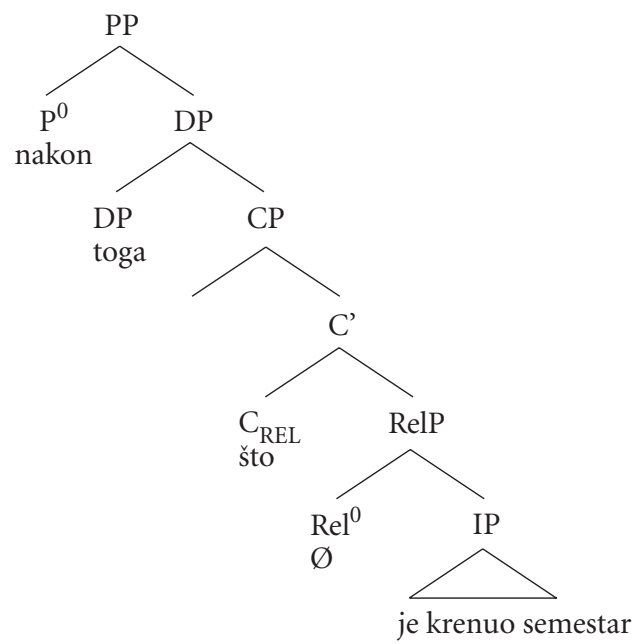

The derivation proceeds exactly as in Hungarian with the difference that in Serbian, the relative determiner is a phonetically empty element. Another difference we find here when compared to the structure proposed for Hungarian, repeated from above in (93), is that in Serbian we have a nominal element, a case-marked to 'that' which receives case from the temporal preposition and which presumably occupies the syntactic head of the relative clause. There is no such nominal element in Hungarian before-type clauses: 
(93)

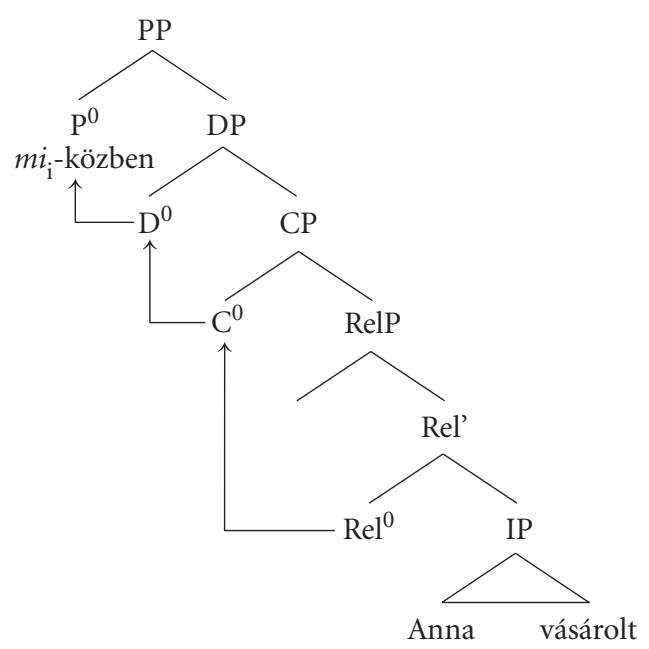

As was argued for Hungarian, the case assigned by the postposition in Hungarian is carried by the $w h$-element $m i$ 'what' that raises to this postposition in a manner indicated in (93). Thus, there is no need for any other nominal that would receive the case.

Our analysis as it stands can thus account for the difference between Serbian and Hungarian in this respect, with the help of the assumption that the demonstrative toga 'that-GEN' is needed only to carry the case assigned by the temporal preposition. There is no other element that could carry the case in Serbian: the relative clause cannot carry case, and within the relative clause there is no element that could pick up this case, either. In this sense, toga 'thatGEN' stands in for the relativized constituent, which, in my analysis is the whole subordinated IP. One possible option for the characterization of the relationship between toga and the relativized IP can be done in the spirit of Citko's (2004) analysis. In these such demonstrative elements are so-called light heads, which differ from ordinary heads of relative clauses. ${ }^{21}$ An example of a light headed relative is given in (94):

$$
\begin{aligned}
& \text { Czytam coś, co lubię. } \\
& \text { read-1sG something what like-1sG } \\
& \text { 'I am reading something I like.' }
\end{aligned}
$$

Light heads, like coss 'something' are semantically empty elements that reduplicate the relativized constituent, in the syntax and sometimes in the morphology as well. Citko argues that (94) needs to receive an analysis in which the element 
that undergoes movement in the relative (co 'what') is copied onto the outside head position: ${ }^{22}$

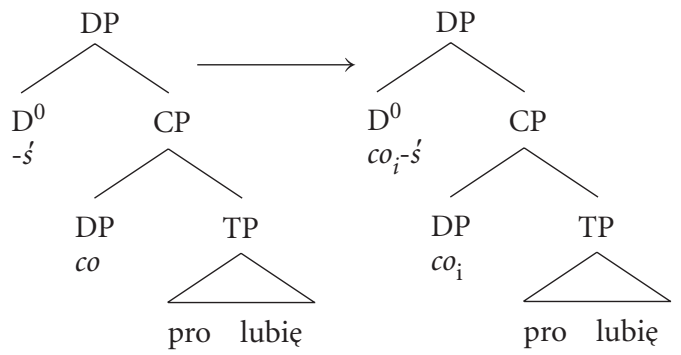

That is, in effect light headed relatives are free relatives that spell out the relativized constituent twice: once in the subordinate clause and once in the head position, the latter due to a copying process.

If we carry over the essence of this analysis to the light head toga that is found in Serbian after-clauses, we can say that toga and the relativized IP are in fact the same constituent. They are related through a copy operation like that shown in (95).

To summarize the results, in this section I showed that Serbian after-clause and because-clauses can be analyzed in terms of IP-relativization, in which the IP found in the temporal subordinated clause is relativized. The preposition nakon 'after' takes this relativized DP as its complement. The analysis was supported by the fact that complex after-clauses do not support a low reading. The proposed structure for Serbian differs only slightly from that of Hungarian before/after-clauses, in that the IP is spelled out twice: once in its base position and once in the external head position, where it appears in the form of a light head. If this analysis is on the right track, the Serbian facts indicate that the light headed strategy is also open to IP-relativization. Under the view which takes light headed relatives to be free relatives (Citko 2004), this is not surprising: IP-relativization in Hungarian and in Serbian are both a free relativization strategy.

\section{A look on other postpositional languages: The split between before-type and since-type clauses again}

The previous section showed that there might be evidence to the effect that IPrelativization does not only occur in Hungarian temporals, as other languages 
also seem to display temporal clauses that could receive an analysis in terms of IP-relativization. This mainly occurs in temporal clauses with before/after.

Why such a strategy is found with before/after-clauses mostly, as opposed to since- or until-clauses, was explained in Section 2.4 above. There it was shown that before/after-clauses, due to their meaning, cannot involve clauseinternal movement of a before/after-expression. Instead, the preposition before/after must combine with the subordinated CP from the outside. Sinceand until-clauses on the other hand can involve ordinary relativization of a since/until-expression inside the subordinated clause, as was argued in Section 2.3 above. As a result of this, within the domain of relativization the following structures are available to the two types of clauses:

(96) [RC REL-wh-SINCE/TILL/WHILE $\left[\right.$ [IP $\left.\left.\ldots e_{i}\right]\right]$ since-type clauses

(97) a. Before/AFter (the time) $\left[\mathrm{RC}\right.$ at $\left.w h_{\mathrm{i}}\left[\mathrm{IP} \ldots \mathrm{e}_{\mathrm{i}}\right]\right]$ before-type clauses b. BEFORE/AFTER [RC $w h[$ IP $\ldots]]$

(96) shows an ordinary relativization strategy, which is available to since-type clauses. ${ }^{23}$ The same structure is excluded for before/after-clauses. What is available to the latter is a strategy in which the relativized expression is an "at time $t$ "-kind of phrase, or a relative clause headed by an (abstract) noun like time (97a). The other possible strategy involves relativization of the subordinated IP (97b), which was shown to happen in Hungarian before/after clauses and German and Serbian after-clauses.

To gain more insight into this difference between before-type and sincetype clauses as well as into the nature of the IP-relativization strategy, it is instructive to look at languages which are similar to Hungarian typologically. When it comes to the expression of temporal relations and relativization in general, Hindi and Basque are suitable for comparison, as both are postpositional agglutinative languages. They are, moreover, very similar in the domain of relativization as well. Both of them use correlativization as a relativization strategy, just like Hungarian (on the latter, see Section 2.3 and Lipták 2005, on Hindi correlatives see Srivastav 1991 or Bhatt 2003, on Basque see Rebuschi 2003, 2004).

Both Hindi and Basque syntactically differentiate between since-type and before-type clauses in a manner that supports the above generalization about the split between these types. Since-type clauses are real relative clauses while beforelafter-clauses are not.

Consider representative facts from Hindi first (Bhatt \& Lipták 2005): 
(98) [RC jab tak John nahii aa jaa-taa ] tab tak mE yahi: when TILL John NEG come HAB then TILL I here rahugaa

(Hindi)

stay-will

'I will stay here until John arrives.'

(99) [DP pacaas-kii umr pahuNc-ne-se ] pahle Dawood do baar 50-GEN age reach.INF-OBL-INST before Dawood two times Haj kar cukaa thaa Haj do complete be.PsT 'Before he reached the age of 50, Dawood had done the Haj twice.'

(98) involves a correlative structure, which contains the temporal clause in which a jab tak 'when TILL' expression is relativized. This is parallel to the Hungarian cases of since-type clauses, which have the same structure (see 13) above:

(100) [(A)mióta ismeri Annát], (azóta) Péter boldog. REL-what-sinCe knows Anna-ACC (that-SINCE) Péter happy 'Since he knows Anna, Péter is happy.'

The Hindi before-clause in (99) on the other hand, does not contain a relative clause of any sort. It clearly involves a nominalized clause: the verb has the form of an infinitive and the whole clause is case-marked.

The facts are similar in Basque as well. Consider the difference between a since-clause in (101) and an after-clause in (102): ${ }^{24}$

(101) [RC Eguzkia atera den-etik] lanean ibili gara. (Basque) sun rise AUX.EN-FROM work.LOC walk AUX

'We have been working since the sun rose.'

(102) [Jon etorr-i ] ondoren joango gara.

Jon come-PRT after go AUX

'After Jon comes, we will go.'

The relative clause nature of the subordinated clause in (101) can be seen from the presence of the relative complementizer -en, which occurs in relative clauses:

(103) [RC haurra ikusi du-en ] gizon.a

child seen AUX-EN man-sG

'the man who has seen the child'

Unlike (101), the subordinated clause in the case of the after-temporal in (102) does not contain a relative complementizer. In fact, it does not contain a finite 
clause to begin with. The subordinated event is expressed in a participial clause without any finite morphology, and thus, without any time reference. This is parallel to the Hindi case of nominalization in (102), where the subordinated clause also lacks finiteness and time reference.

The basic syntactic split that Hindi and Basque employs between since- and before-type clauses is that between relativization versus nominalization:

(104) [RC REL-wh-SINCE/TILL/WHILE $\left[\right.$ IIP $\left.\left.\ldots e_{i}\right]\right]$ since-type clauses

(105) BEFORE/AFter $[$ NOM $[$ IP(-fin) $\ldots]$. before-type clauses

Due to nominalization, the subordinated material is fed to the postpositions before and after in the manner of ordinary nominal complements (before the lecture). The postpositions express temporal ordering between the event denoted by the nominalized VP and the event denoted by the matrix clause. This is in line with the semantics that forbids before/after to occur inside the subordinated material.

In connection with the phenomenon of nominalization it has to be noted that the IP-relativization strategy that was suggested for Hungarian beforelafter-clauses can in a way be considered as a syntactic alternative to nominalization, to the extent that it turns an event into a nominal category and serves the same function as nominalization in Hindi/Basque temporals. Consider the structure of a Hungarian IP-relative again:

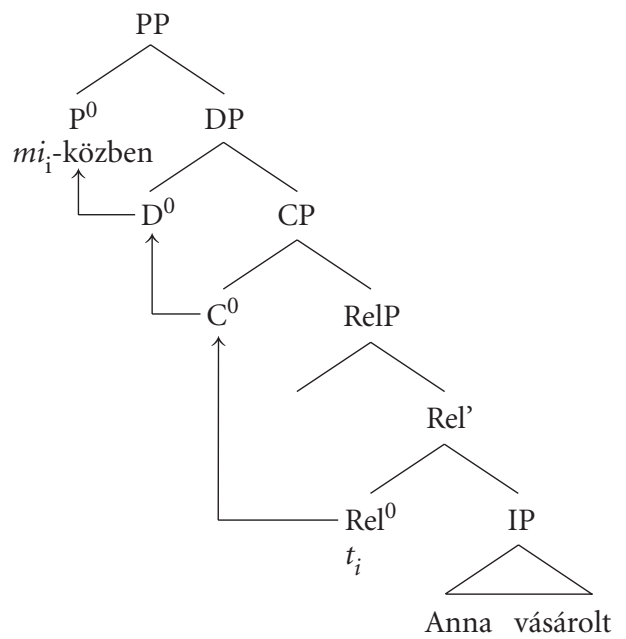

As a result of the relativization process that affects the IP, which encompasses all subordinated material in fact, the subordinated clause comes to function 
externally as a nominal constituent and thus serves as a suitable complement to the postposition. The reason why Hungarian uses IP-relativization instead of ordinary nominalization must be due to the fact that the latter mechanism is not a productive pattern in Hungarian, unlike in Hindi or Basque. ${ }^{25}$

Before closing this crosslinguistic section, let us turn to issues of linguistic variation more generally. As we have seen in this and the previous sections, languages can greatly vary in what syntactic strategy they use in the expression of before-type temporal adjunct clauses. In the small number of languages that the present paper looked at, Hungarian uses IP-relativization, Basque and Hindi uses nominalizations, and yet other languages use movement of a whenlike empty operator inside a finite clause. Seeing such a great amount of variation, it is natural to ask the question: why are there so many strategies and what determines which strategy a particular language uses?

I believe the answer to these questions lies in the lexical properties of the involved expressions in languages. Lexical properties of words are to a large extent accidental and can thus give rise to substantial linguistic variation across languages. In the domain of temporal clauses, languages differ first of all in what kind of elements are available in them for the expression of the before/after semantic relation. Such a relation can be expressed by temporal or locative pre- and postpositions, case-markers as well as aspectual forms or independent nominals. Even languages that use the same kind of item to express a before/after relation can differ in what particular lexical properties this element has, most notably, what its selectional properties are. To stay with our small pool of languages, the postposition elott 'before' in Hungarian differs from the English preposition before in that elótt cannot take finite CP complements, while before arguably can. For Hungarian, this rules out the existence of a finite clause stategy in which before is complemented by a CP. Instead, the language has to resort to a strategy in which elótt can combine with a nominal constituent. In case clausal nominalization is unavailable to provide elott with the required nominal complement, a relative clause strategy has to come into play. What relative clause strategy is selected also shows substantial variation, too. If a language lacks $w$ h-expressions that correspond to temporal phrases, or these phrases would give rise to the wrong meaning, ordinary relative clause formation cannot proceed for want of lexical material. The purpose of the present paper was to show that in this particular case, a language can resort to another strategy: it can relativize functional material instead, a whole IP. To what extent is this a last resort strategy that languages use only when all else fails, I leave for future research. 


\section{Summary}

This paper discussed the syntax of temporal adverbial clauses, focusing on systematic differences that can be found between before/after- and since/until-type temporal clauses. It was shown that the two types involve different structures in a number of languages. It was argued that the basic split between these two types can be partly described by a simple generalization rooted in the semantics of these clauses: before and after cannot originate from inside the subordinate clause, unlike the prepositions since and until. This entails that since-type clauses can take the form of ordinary relatives, while before/after-clauses cannot. There is an alternative relativization strategy open to the latter though, which was isolated in Hungarian. This involves relativization of clausal material, the whole IP in the temporal clause. The relativization process that involves this functional constituent was accommodated in the head raising analysis. Next to giving a detailed analysis of Hungarian temporal clauses, the paper considered the internal structure of temporal IP-relatives in other languages as well. It provided suggestive accounts of German and Serbian after-clauses along the lines of IP-relativization, too. On the basis of comparison with nominalization data in Basque and Hindi, it was concluded that the newly discovered IP-relativization can be thought of as a syntactic alternative to nominalization of clauses.

\section{Notes}

* This paper owes a great deal to Rajesh Bhatt and Marcel den Dikken in many respects. I thank them both for their generous input into projects carried out with me on very similar topics as well as for their comments on the present paper, which is essentially a spin-off of these projects. Section 2.3 benefitted from Bhatt and Lipták (2005), while Section 3.1 and 4.1 borrow the underlying idea from den Dikken and Lipták (1997). I am also very grateful for the detailed and careful comments of the anonymous reviewer, which improved this paper considerably. Thanks also to Boban Arsenijević, Ricardo Etxepare and Martin Salzmann for their help with the Serbian, Basque and German facts respectively. All errors and shortcomings are mine. This research is funded by NWO (Netherlands Organization for Scientific Research.)

1. Although not much hinges on this, I subscribe to the view that the operator in free relative clauses occupies a clause-internal position (Spec,CP), as in the so-called Comp-account, which originates from Groos and van Riemsdijk (1979). 
2. The glosses in this paper are as follows: $\mathrm{ACC}=$ accusative case; $\mathrm{AUX}=$ auxiliary; $\mathrm{DAT}=\mathrm{da}-$ tive; $\mathrm{ERG}=$ ergative case; $\mathrm{GEN}=$ genitive; $\mathrm{HAB}=$ habitual marker; $\mathrm{INF}=$ infinitive; $\mathrm{INST}=$ instrumental; $\mathrm{OBL}=$ oblique; $\mathrm{OBS}=$ obsolete case-marker; POSs = possessive; $\mathrm{PRT}=$ participle; PST $=$ past $; \mathrm{PV}=$ preverb $(\mathrm{al}$ element $) ; \mathrm{REL}=$ relative morpheme; $\mathrm{RC}=$ relative clause; $\mathrm{SUB} \mathrm{J}$ $=$ subjunctive; $1 / 2 / 3 / \mathrm{sG} / \mathrm{PL}=$ person, number features. Nominative/absolutive case is not glossed throughout. Person/number features on verbs are only indicated when the subject is pronominal.

3. I borrow this term from Potts (2002a, 2002b). We return to clausal non-restrictive relatives in Section 3.3 below.

4. For the general syntactic properties of case-markers and postpositions in Hungarian, see Marácz (1989).

5. Postpositional phrases with full nominals or demonstratives are spelled in two words in Hungarian orthography. Temporal demonstratives occurring in the finite strategy (azután 'that-after'), as well as all $w h$-expressions to be reviewed on the next page are always spelled as one word.

6. For presentational purposes and ease of exposition the list in (12)-(19) is not fully exhaustive: it contains only those wh-clauses in which the case-marker/postposition on the wh-expression has a regular distribution (i.e. they can also occur with nominal expressions like five o'clock, two months, etc.) Next to (12)-(19), there are a few temporal clauses which contain wh-expressions that are either marked with obsolete case forms (marked as oвs) that do not occur with ordinary nominals or, if they do, not with a temporal meaning:

(i) [(A)midőn Péter meglátta Annát], kiabálni kezdett.

(archaic) REL-what-obs Péter saw Anna-ACC shout-INF began

'When Péter got to see Anna, he started shouting.'

(ii) $[$ Mihely(s)t Péter meglátta Annát], kiabálni kezdett. REL-what-obs Péter saw Anna-ACC shout-INF began

'As soon as Péter got to see Anna, he started shouting.'

(iii) [Amint Péter meglátta Annát], kiabálni kezdett. REL-what-As Péter saw Anna-ACC shout-INF began

'As (soon as) Péter got to see Anna, he started shouting.'

Note also that next to (a)meddig 'rel-what-till/while', a synonymous shorter form amig 'RELwhat-TILL/WHILE' also exists, with the same meaning as (a)meddig 'REL-what-TILL/WHILE':

(iv) [(A)míg Anna vásárolt], Péter megnézte a postáját. REL-what-TILL/while Anna shopped Péter checked the mail-his-ACC 'While Anna was shopping, Péter checked his mail.'

Due to their irregular character, I do not deal with the sentence types in (i)-(iv) in the paper.

7. A-marking on relative $w h$-expressions is a relatively late development in Hungarian. Earlier stages of the language featured bare $w h$-items in relative clauses. For an illustration of old Hungarian data, see Kenesei (1992). 
8. It has to be noted that very very rarely one might find mielótt 'what-BEFORE', miután 'what-AFTER', mialatt 'what-UNDER', miközben 'what-wHILE' occurring with an $a$-. Kenesei et al. (1998) mentions the following as grammatical for example:

(i) Azelőtt [amielött Anna megérkezett], olvasott.

that-BEFORE REL-what-BEFORE Anna arrived read

'Before Anna arrived, she read.'

I contend that such $a$-marked forms are either restricted to a small dialect, or reflect performance errors, maybe due to overgeneralization on the basis of the $a$-marked pattern of (a)mikor 'REL-what-AT', (a)mióta 'REL-what-SINCE' and (a)mire 'REL-what-BY'. A simple Google-seach for the former items clearly indicates how infrequent examples like (i) are. A search for amialatt 'REL-what-UNDER' resulted in a negligible 102 hits compared to the 41,000 hits that turned up for mialatt 'what-UNDER'. Amiután 'REL-what-AFTER' was hit 794 times, while miután 'what-AFTER' about 440,000 times. Note that a similar Googlesearch about the $a$-marked and $a$-less forms of the $a$-marked group ( $(a)$ mikor 'REL-what-AT', (a) mióta 'REL-what-SINCE' and (a)mire 'REL-what-BY', ameddig 'REL-what-WHILE') resulted in a very high number for both forms (well above 100,000 hits).

9. Note that since-type temporals cannot modify ordinary nominals like a koncert 'the concert' without the loss of some degree of grammaticality:

(i) ?? a koncert [amikor Anna elájult] the concert REL-what-AT Anna fainted 'the concert when Anna fainted'

Before-type temporals are fully ungrammatical in the same context:

(ii) *a koncert [miután Anna elájult]

the concert what-AFTER Anna fainted

'the concert after which Anna fainted'

10. As expected, the mirror-image counterpart of (33), in which the achievement predicate is in the main clause and the activity predicate is in the temporal clause, is also ungrammatical:

(i) ${ }^{\star A}$ vonat megjött [ameddig Sára beszélgetett].

the train arrived REL-what-TILL/WHILE Sára chatted

'The train arrived during the time Sára was chatting.'

This is due to the same restriction that explains the ungrammaticality of (33) as well. In the case of (i) it is the main clause achievment predicate which is incompatible with the until-expression (the temporal clause).

11. Idiomatic expressions with units of time are exceptions. These are grammatical: napközben 'day-DURING' during the day, hétközben 'week-DURING' during the week.

12. Note that ortography differs in this case: $m i$ is spelled in a separate word from the postposition, unlike in temporal $w h$-expressions (cf. fn. 5 above). 
13. Alatt is slightly less restrictive than közben when combining with time-expressions. It allows measure phrases as well:
a. az elóadás alatt
b. öt óra alatt five house in
the lecture in
'in five ours'
c. *holnap alatt tomorrow IN
'tomorrow'

Nevertheless, due to (ic), alatt cannot combine with a default temporal wh-expression either (as that is a non-measure item):
(ii) ${ }^{\star}$ Mialatt ment ki Péter?
what-IN went PV Péter
'During what period did Péter leave?'

14. Note that the default temporal question is unconstructable in English, too, with these prepositions: ${ }^{\star}$ before when, ${ }^{\star}$ after when, ${ }^{\star}$ during when. English fully sides with Hungarian in not allowing default time expressions after these prepositions.

15. The analysis to be sketched is taken from den Dikken and Lipták (1997).

16. Although (66) is not a very telling example, given that CPs with overt complementizers cannot function as root clauses. A more relevant example can be the following one, in which the relativized material is a $w h$-question, and is thus a full CP. Questions that clearly correspond to full CPs, i.e. non-subject questions, are ungrammatical in clausal relativization in English:

(ii) a. Who arrived, after which Peter left?

b. ${ }^{*}$ When did Anna arrive, after which Peter left?

17. The gist of this section is taken from den Dikken and Lipták (1997).

18. Note that Dutch also has a temporal clause (albeit used as a conditional in present day Dutch) that features a demonstrative pronominal dien (an obsolete case form):

(i) John vertrekt indien Bill aankomt.

John leaves in-that-GEN Bill arrives

'John leaves if Bill arrives.'

Regular temporal clauses with before/after in Dutch also use a demonstrative item, dat:

(ii) John vertrekt voordat/nadat Bill aankomt.

John leaves BEFORE-that/AFTER-that Bill comes

'John leaves before/after Bill comes.'

Dat in Dutch is both a relative pronoun and a finite complementizer. Thus, unlike (i), the examples in (ii) do not lend straightforward evidence for the claim that before/after clauses in Dutch are relative clauses.

19. Before-clauses have a very similar structure, except that they involve the comparative element nego 'than': 
(i) Jovan je kupio knjigu pre nego što je poceo semestar.

Jovan AUX-3SG bought book before than $\mathrm{C}_{\mathrm{REL}}$ AUX-3SG started semester 'Jovan bought the book before the semester started.'

I set before-clauses aside in the rest of this section, noting that the gist of the discussion about after-clauses can be extended to these.

20. Browne (1986) mentions that sentential embedding used in a sentence that expresses an emotional reaction, can occur with što:

(i) Radujem se što ste stigli.

be.glad-1sG REFL that AUX-2sg came

'I am glad that you came.'

21. 'Head' is to be understood here in the traditional, pre-Kaynean sense of the word.

22. Note that the copy operation does not necessarily result in morphological indentity between the relativized constituent and the light head. When the light head is quantificational, there is no such identity. Consider the Dutch example in (i):

(i) alles wat ik lees

everything what I read

'everything I read'

23. Iatridou and von Fintel (2001) show that some since-clauses in English have a similar structure, too.

24. The examples are illustrative but not exhaustive here: Basque has many other ways of expressing temporal relations than the two mentioned in (101) and (102): since/until-clauses can also be expressed by means other than relativization. Before/after-clauses on the other hand cannot be expressed in the form of a relative clause. See Hualde and Ortiz de Urbina (eds.) (2003) for all patterns and facts.

25. The restricted nature of Hungarian nominalization is indicated by the fact that until very recently, it was not even known that Hungarian can nominalize clausal material. Nominalization was considered a lexical derivational process (Szabolcsi 1994) and thus unavailable to clausal material. Kenesei (to appear) is the first to argue that Hungarian has a clausal nominalization strategy which should be considered syntactic.

\section{References}

Artstein, R. to appear. "Quantificational arguments in temporal adjunct clauses". Linguistics and philosophy.

Bhatt, R. 2003. "Locality in Correlatives". Natural Language and Linguistic Theory 21.485541.

- \& A. Lipták. 2005. “Temporal correlatives”. Ms., University of Amherst/University of Leiden.

Browne, W. 1986. Relative clauses in Serbo-Croatian. (New Studies Series). Zagreb. 
\& T. Alt. 2004. A handbook of Bosnian, Serbian and Croatian. (The Slavic and East European Language Research Center reference grammars). http://seelrc.org:8080/grammar/pdf/stand_alone_bcs.pdf

Canac-Marquis, R. \& M. Tremblay. 1998. "The wh-feature and the syntax of restrictive and non-restrictive relatives in French and English". Theoretical Analyses on Romance Languages ed. by José Lema and Esthela Treviño. Amsterdam \& Philadelphia: John Benjamins.

Chomsky, N. 1977. “On wh-movement”. Formal syntax ed. by P. Culicover, T. Wasow \& A. Ackmajian, 71-132. New York: Academic Press.

Citko, B. 2000. "On the syntax and semantics of Polish Adjunct Clauses". Journal of Slavic Linguistics 8.1-38.

_ 2004. "On Headed, Headless and Light-headed Relatives". Natural Language and Linguistic Theory 22.95-126.

Dikken, M. den \& A. Lipták. 1997. “After-thoughts” Ms., ZAS, Berlin.

Geis, M. L. 1970. Adverbial subordinate clauses in English. Ph.D. dissertation, MIT.

Grimshaw, J. 1997. "Projection, heads and optimality". Linguistic Inquiry 28.373-422.

Groos, A. and H. van Riemsdijk. 1979. "Matching effects in free relatives: A parameter of core grammar". Theory of markedness in a generative grammar ed. by A. Belletti. Pisa: Scoula Normale Superiore.

Hualde, J. L. \& J. Ortiz de Urbina, eds. 2003. A grammar of Basque. Berlin \& New York: Mouton de Gruyter.

Iatrodou, S. \& K. von Fintel. 2001. "Since since”. Ms., MIT. Available at: www.web.mit.edu/finte/www/since.pdf.

Karttunen, L. 1974. “Until”. Proceedings of Chicago Linguistic Society 10.284-297.

Kayne, R. 1994. The Antisymmetry of syntax. Cambridge, MA: MIT Press.

Kenesei, I. 1992. "On Hungarian Complementizers." Approaches to Hungarian 4 ed. by I. Kenesei \& Cs. Pléh, 37-50. Szeged: Jate Press.

Kenesei, I. 1994. "Subordinate Clauses". The Syntactic Structure of Hungarian ed. by F. Kiefer \& K. É. Kiss, 275-354. San Diego: Academic Press.

- to appear. "Nonfinite clauses in derived nominals". Approaches to Hungarian 9 ed. by I. Kenesei, P. Siptár \& C. Piñón. Budapest: Akadémiai Kiadó.

R. Vago \& A. Fenyvesi. 1998. Hungarian. (Routledge Grammars). London: Routledge.

Larson, R. 1988. Extraction and multiple selection in PP. The Linguistic Review 7.169-182.

Lipták, A. 2000. "Multiple relatives as relatives of questions". Approaches to Hungarian 8 ed. by I. Kenesei \& P. Siptár, 153-177. Szeged: Jate Press.

Lipták, A. 2005. “Correlative topicalization”. Ms., Leiden University.

Marácz, L. 1989. Asymmetries in Hungarian. Ph.D. dissertation, Groningen University.

Potts, Ch. 2002a. "The lexical semantics of parenthetical-as and appositive-which". Syntax 5.1.55-88.

2002b. "The syntax and semantics of as-parentheticals". Natural Language and Linguistic Theory 20. 623-689. 
Rebuschi, G. 2003. "Towards a theoretical treatment of left-dislocated subordinate clauses". P. Lafitteren sortzearen mendemugako biltzarra, I: Gramatika gaiak coll. IKER ed. by J. M. Makazaga \& B. Oyharçabal, 395-416. Bilbao: Euskaltzaindia.

Rebuschi, G. 2004. "Basque Semi-Free Relative clauses and the Structure of DPs". Lapurdum 8, 2003.457-477.

Srivastav, V. 1991. "The Syntax and Semantics of Correlatives". Natural Language and Linguistic Theory 9.637-686.

Szabolcsi, A. 1992. "Articles and Complementizers". Approaches to Hungarian 4 ed. by I. Kenesei \& Cs. Pléh, 123-140. Szeged: Jate Press.

1994. “The Noun Phrase." The Syntactic Structure of Hungarian ed. by F. Kiefer \& K. É. Kiss, 179-274. San Diego: Academic Press.

Szucsich, L. 2003. "The Structure of Relative Clauses in Slavic", Investigations into Formal Slavic Linguistics ed. by P. Kosta, J. Błaszczak, L. Geist \& J. Frasek, vol. II, 697-714. Frankfurt/Main: Peter Lang.

Thompson, S. A. \& R. E. Longacre. 1985. “Adverbial clauses”. Language typology and syntactic description, ed. by T. Shopen, Cambridge: Cambridge University Press.

Tsoulas, G. 1995. "Indefinite clauses: Some notes on the syntax and semantics of subjunctives and indefinites". Proceedings of WCCLF 13. Stanford: CSLI Publications. de Vries, M. to appear. "The syntax of appositive relativization”. Linguistic Inquiry. 
Copyright of Linguistic Variation Yearbook is the property of John Benjamins Publishing Co. and its content may not be copied or emailed to multiple sites or posted to a listserv without the copyright holder's express written permission. However, users may print, download, or email articles for individual use. 